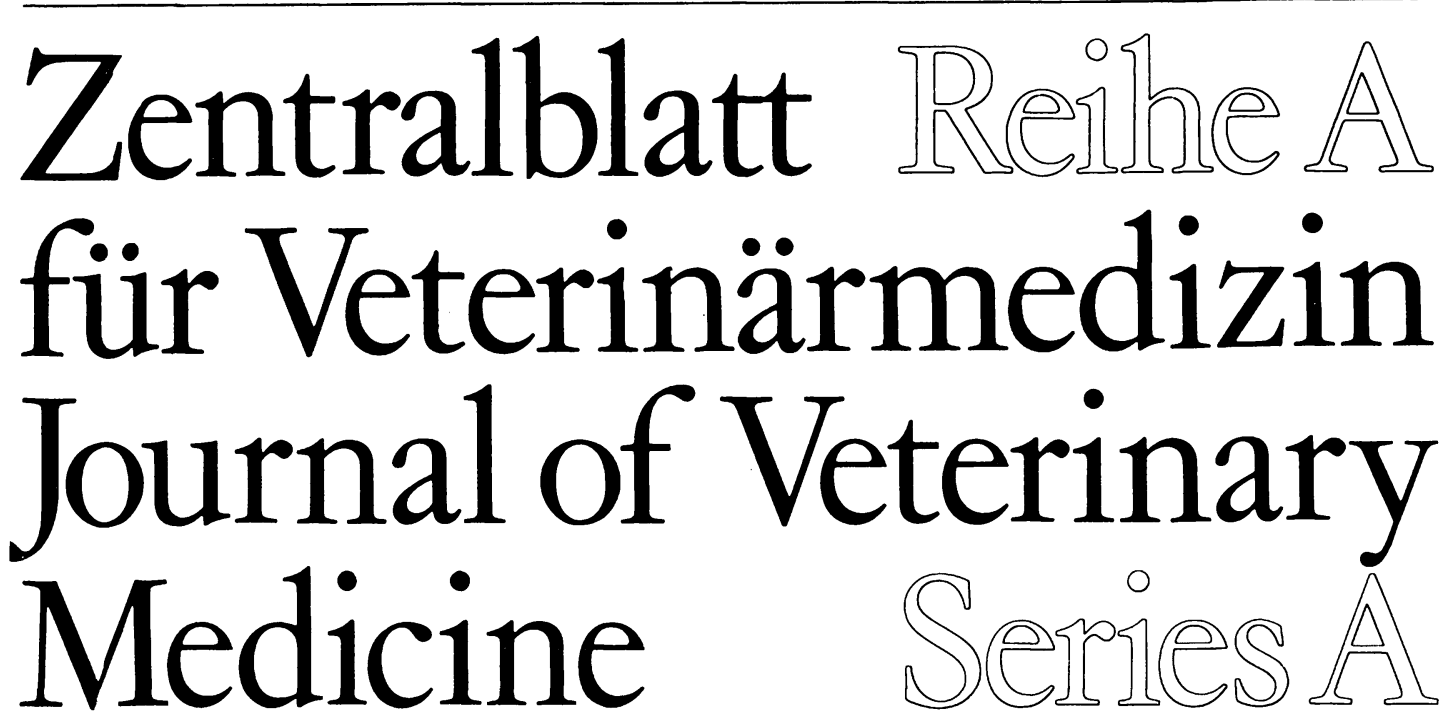

Animal Physiology, Pathology and Clinical Veterinary Medicine

\title{
Inhalt / Contents
}

\section{Originalarbeiten / Original Papers}

S. Tuček, T. Svoboda, J. Řičný, A. Bass, T. Soukup and V. Vítek: The Concentration of Choline and the Activities of Cholinesterases, Creatine Kinase and Lactate Dehydrogenase in the Blood Plasma of Piglets with the Syndrome of

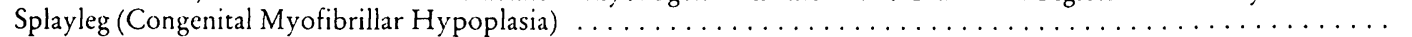

G.H. Géorgiev, Kréména Gaydarova, R. Stanislavov et D. Barov: Distribution et Activité de la NicotinamideAdénine-Dinucléotide-Nucléosidase dans le Plasma Seminal des Mammifères. (Distribution and activity of nicotinamide adenine dinucleotide nucleosidase in mammalian seminal plasma $) \ldots \ldots \ldots \ldots \ldots \ldots \ldots \ldots \ldots \ldots \ldots$

L. Andersson and K. Lundström: Effect of Feeding Silage with High Butyric Acid Content on Ketone Body

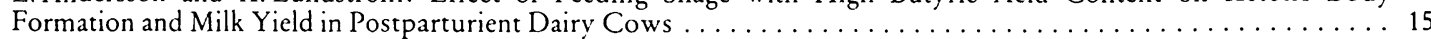

Heidrun Schniedewind und S. Paufler: Die Meiose-Chromosomen der Regenbogenforelle (Salmo gairdneri).

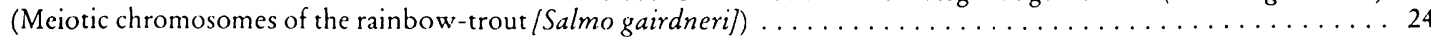

Heidrun Schniedewind, H.W. Michelmann und S. Paufler: Die Mitose-Chromosomen der Regenbogenforelle (Salmo gairdneri). (Mitotic chromosomes of the rainbow-front /Salmo gairdneri]) $\ldots \ldots \ldots \ldots \ldots \ldots \ldots \ldots \ldots$

T. U. Obi: Casein-Induced Anaphylactic-Type acute Respiratory Distress Syndrome in Calves

A. P. Singh, Jit Singh, P. K. Peshin, J. S. Gahlawat, Prem Singh and J. M. Nigam: Evaluation of Xylazine-Ketamine

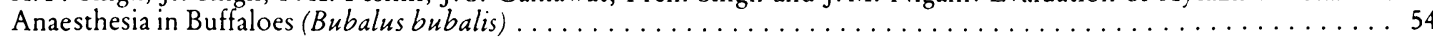

R. Deppe y J. De Grenade: Empleo de la Asociación Propionilpromazina-Meperidina en la Anestesia con Tiopental Sódico en el Caballo. (Propionylpromazine and Meperidin for premedication of Thiopentalnarcosis in the horse) 59

H. A. Greife: Zum Einfluß der Verwertungshöhe des Futterstickstoffs auf die Verteilung einzelner N-Fraktionen im Rattenharn. (Influence of the level of utilisation of dietary nitrogen on the distribution of $\mathrm{N}$-fractions in the urine of

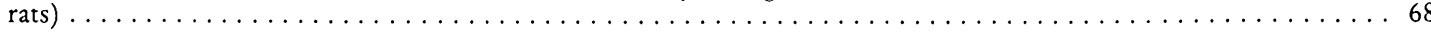

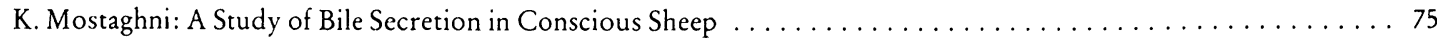


The evaluation of the papers is made by a team of specialists who decide about possible acceptance, changes, or rejection. No changes will be made without the approval of the author.

\section{Zentralblatt für Veterinärmedizin, Reihe A Journal of Veterinary Medicine, Series A}

Herausgegeben von/Edited by
M. BERCHTOLD
A. Mayr
H. SPÖRRI
E. G. White
Zürich
München
Zürich
Liverpool

unter Mitarbeit von/Editorial Board

Adler, Kopenhagen; Ahmed, Alexandria; Arbeiter, Wien; Bamberg, Wien; Boch, München; Bonadonna, Mailand; de Cuenca, Madrid; Dirksen, München; Ekman, Uppsala; Ercegovac, Belgrad; Fritzsche, Koblenz; Gerber, Bern; Glawischnig, Wien; Grossklaus, Berlin; Grunert, Hannover; Hansen, Stockholm; Holub, Brünn; Horzinek, Utrecht; Merkenschlager, München; Parodi, Alfort; Ramyar, Teheran; Robinson, Sydney; Schiefer, Saskatoon; Schliesser, Gießen; Siegmann, Hannover; Storz, Baton Rouge; Strauch, Hohenheim; Stünzi, Zürich; Tanaka, Tokio; Teunissen, Utrecht; Tillmann, Gießen; Traub, München; Truszczyński, Pulawy; Vandeplassche, Gent; Wachendörfer, Frankfurt; Walton, Liverpool; Weber, Philadelphia; Westermarck, Helsinki; Wintzer, Berlin; Wittke, Berlin; Wittmann, Tübingen; Zamora, Valdivia; Ziv, Beit Dagan 


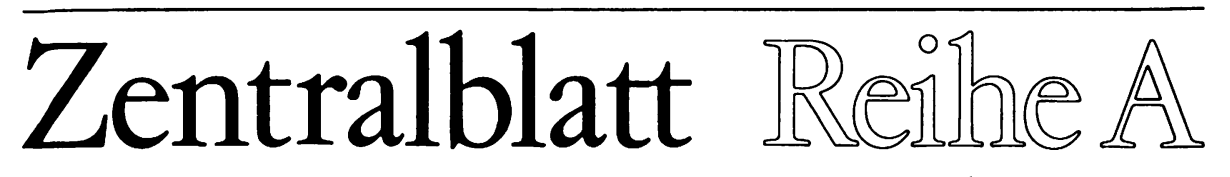
für Veterinärmedizin Journal of Veterinary Medicine

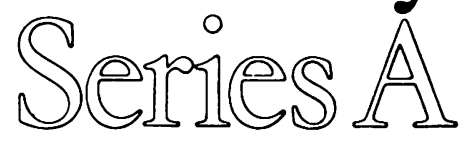

Animal Physiology, Pathology and Clinical Veterinary Medicine

Herausgegeben von / Edited by

$\begin{array}{llll}\text { M. BERCHTOLD } & \text { A. MAYR } & \text { H. SPÖRRI } & \text { E.G. WhITE } \\ \text { Zürich } & \text { München } & \text { Zürich } & \text { Liverpool }\end{array}$

BAND/VOLUME 32, 1985

287 Abbildungen/Figures

166 Tabellen/Tables

Verlag Paul Parey · Berlin und Hamburg 
Adler, Kopenhagen; Ahmed, Alexandria; Arbeiter, Wien; Bamberg, Wien; Boch, München; Bonadonna, Mailand; de Cuenca, Madrid; Dirksen, Muinchen; Ekman, Uppsala; Ercegovac, Belgrad; Fritzsche, Koblenz; Gerber, Bern; Glawischnig, Wien; Grossklaus, Berlin; Grunert, Hannover; HanSEn, Stockholm; Holub, Brünn; Horzinek, Utrecht; Merkenschlager, München; Parodi, Alfort; Ramyar, Teheran; Robinson, Sydney; Schiefer, Saskatoon; Schliesser, Gießen; Siegmann, Hannover; Storz, Fort Collins; Strauch, Hohenheim; Stünzi, Zürich; Teunissen, Utrecht; Tillmann, Gießen; Truszczyński, Pulawy; Vandeplassche, Gent; Wachendörfer, Frankfurt; Walton, Liverpool; Weber, Philadelphia; Westermarck, Helsinki; Wintzer, Berlin; Wittke, Berlin; Wittmann, Tübingen; Zamora, Valdivia; Ziv, Beit Dagan

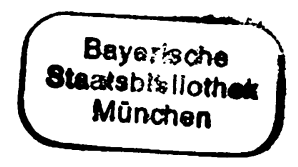

Vorbehalte aller Rechte: Die in dieser Zeitschrift veröffentlichten Beiträge sind urheberrechtlich geschützt. Die dadurch begründeten Rechte, insbesondere die der Übersetzung, des Nachdrucks, des Vortrags, der Entnahme von Abbildungen und Tabellen, der Funk- und Fernsehsendung, der Mikroverfilmung oder der Vervielfältigung auf anderen Wegen sowie der Speicherung in Datenverarbeitungsanlagen, bleiben, auch bei nur auszugsweiser Verwertung, vorbehalten. Das Vervielfältigen dieser Zeitschrift ist auch im Einzelfall grundsätzlich verboten. Die Herstellung einer Kopie eines einzelnen Beitrages oder von Teilen eines Beitrages ist auch im Einzelfall nur in den Grenzen der gesetzlichen Bestimmungen des Urheberrechtsgesetzes der Bundesrepublik Deutschland vom 9. September 1965 in der Fassung vom 24. Juni 1985 zulässig. Sie ist grundsätzlich vergütungspflichtig. Zuwiderhandlungen unterliegen den Strafbestimmungen des Urheberrechtsgesetzes. Gesetzlich zulässige Vervielfältigungen sind mit einem Vermerk über die Quelle und den Vervielfältiger zu kennzeichnen.

Copyright-masthead-statement (valid for users in the USA): The appearance of the code at the bottom of the first page of an article in this journal indicates the copyright owner's consent that copies of the article may be made for personal or internal use, or for the personal or internal use of specific clients. This consent is given on the condition, however, that the copier pay the stated percopy fee through the Copyright Clearance Center, Inc., 21 Congress Street, Salem, MA 0 1970/USA for copying beyond that permitted by Sections 107 or 108 of the U.S. Copyright Law. This consent does not extend to other kinds of copying, such as copying for general distribution, for advertising or promotional purposes, for creating new collective, or for resale. For copying from back volumes of this journal see "Permissions to Photo-Copy: Publisher's Fee List" of the CCC.

This journal is covered by Biosciences Information Service of Biological Abstracts, Current Contents (Series Agriculture, Biology \& Environmental Sciences), Science Citation Index and Automatic Subject Citation Alert of Institute for Scientific Information, Index Medicus and Medlars of National Library of Medicine, Chemical Abstracts (selectively), Nutrition Abstracts and Reviews of the Commonwealth Bureau of Animal Nutrition, Index Veterinarius and The Veterinary Bulletin of the Commonwealth Bureau of Animal Health, and Vetdoc of Derwent Publications Ltd.

Verantwortlich gemäß Berliner Pressegesetz: DDr. h.c. Friedrich Georgi, Lindenstr. 44-47, D-1000 Berlin 61 (c) 1985 Paul Parey, Berlin und Hamburg, Verlag: Paul Parey. Anschriften: Lindenstraße 44-47, D-1000 Berlin 61: Spitalerstraße 12, D-2000 Hamburg 1

Printed in Germany by Saladruck, Köpenicker Straße 18-20, D-1000 Berlin 36. 


\section{Inhaltsverzeichnis zum zweiunddreißigsten Band Index Vol. 32}

An unsere Leser und Autoren / To our Readers and Authors . . . . . . . . . . . .

481

An unsere Leser / To our Readers

vor 641

\section{Originalarbeiten / Original Papers}

Abdelsalam, E. B., and E. J. H. Ford: Normal Esterase Activity in the Plasma, Whole Blood

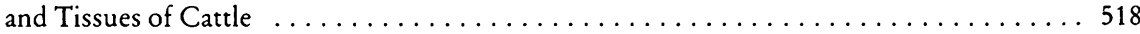

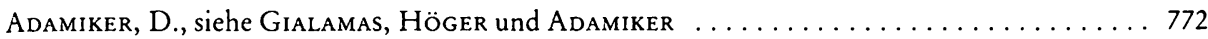

Aharon, D. C., siehe Sekeles, Aharon and Fass ....................... 226

Amelang, D., K. Gärtner and H.J. Hedrich: Does the MHC Influence Fertility of Male Rats? ....................................... 391

Andersson, L., and K. Lundström: Effect of Feeding Silage with High Butyric Acid Content on Ketone Body Formation and Milk Yield in Postparturient Dairy Cows ............

AugsBurger, H.: Elektronenmikroskopische Untersuchung der Milchdrüseninvolution bei Ziegen. (Electronmicroscopic studies on mammary gland involution in the goat) $\ldots \ldots \ldots 337$

Augsburger, H., siehe Geyer, Rüsch, Giese und Augsburger . . . . . . . . . . . . . . 331

Bamberg, E., H. S. Choi, E. Möstl und A. Scharf: Anwendbarkeit der Östrogenbestimmung im Kot zur Trächtigkeitsdiagnose beim Rind. (Applicability of oestrogen determination in faeces for pregnancy diagnosis in cattle) ......................... 119

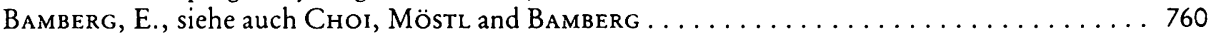

Barov, D., siehe Géorgiev, Gaydarova, Stanislavov et Barov . . . . . . . . . . . . . 11

Bass, A., siehe Tucek, Svoboda, Ricný, Bass, Soukup and Vitek . . . . . . . . . . . . 1

van Beukelen, P., Th. Wensing and H.J. Breuking: Effects of Feeding Chopped-Hay Rations on Lipid Metabolism and Milk fat Production in High Yielding Dairy Cows . . . 561

Blum, J. W., F. Jans, W. Moses, D. Fröhli, M. Zemp, M. Wanner, I. C. Hart, R. Thun and U. Keller: Twentyfour-Hour Pattern of Blood Hormone and Metabolite Concentrations in High-Yielding Dairy Cows: Effects of Feeding Low or High Amounts of Starch, or

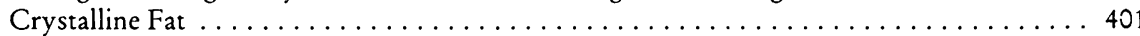

Bobek, S., siehe Pierzchala, Niezgoda and Bobek ..................... 140

Bogin, E., S. Soback and A. Immelman: Transketolase Activity in the Blood of Cattle and Sheep in Relation to Thiamine Deficiency . . . . . . . . . . . . . . . . . . 135

Bollwahn, W., siehe Kirchgessner, Roth, Bollwahn und Heinritzi $\ldots \ldots \ldots \ldots \ldots \ldots 641$

Bollwahn, W., siehe auch Roth, Kirchgessner, Bollwahn und Heinritzi . . . . . . 652

Braun, U., D. Schams and W. Leidl: Effects of Gonadotropin-Releasing Hormone on the Release of Luteinizing Hormone and Follicle-Stimulating Hormone from Bovine Anterior Pituitary Cell Cultures . . . . . . . . . . . . . . . . . . . . . . . . 594

Breuking, H.J., siehe van Beukflen, Wensing and Breuking ............... 561

Chauhan, H. V. S., siehe K. K. Singh, Jha, Chauhan and P. N. Singh . . . . . . . . . . 437

Choi, H.S., E. Möstl and E. Bamberg: Confirmation of Pregnancy in Mares by Enzyme Immunoassay of Oestrogens in Faeces . . . . . . . . . . . . . . . . . 760

Choi, H. S., siehe auch Bamberg, Choi, Möstl und Scharf . . . . . . . . . . . . 119

Claus, R., D. Schopper, H.-G. Wagner and U. Weiler: Photoperiodic Influences on Reproduction of Domestic Boars. I. Light Influences on Testicular Steroids in Peripheral Blood Plasma and Seminal Plasma . ................................. 86

Claus, R., U. Weiler and H.-G. Wagner: Photoperiodic Influences on Reproduction of Domestic Boars. II. Light Influences on Semen Characteristics and Libido . . . . . . . . . .

Costa, G., M. Illera and A. García-SAcristán: Electrocardiographical Values in NonTrained Horses . . . . . . . . . . . . . . . . . . . . . . . . . . . . 196

Costa, G., siehe auch García-Sacristán, Costa and Labadia . . . . . . . . . . . . . 179

Dahir, A. M., A. Hild, K. D. Weyrauch und W. Gehring: Licht- und elektronenmikroskopische Untersuchungen an den Uterindrüsen des Rindes im hormonell induzierten Zyklus. (Light and electronmicroscopical studies on the uterine gland of the cow during hormo-

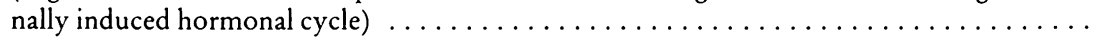


Dahme, E., siehe Manne, Pospischil und Dahme..................... 467

Df̧Bski, B., and S. Pierzynowski: Changes of the Portal Blood Flow Caused by Intravenous Ammonium Chloride Infusion in Rabbits ...................... 616

DȨBSKI, B.: The Effect of Training and Physical Exercise on the Energetic Metabolism of Equine Erythrocytes

Degórski, A., J. Prandota, R. Lechowski and E. Miernik: Serum Lysozyme Activity in Relation to the Nitroblue Tetrazolium Reduction Test in Newborn Calves and Cows . . . . 241

Deppe, R. y J. De Grenade: Empleo de la Asociación Propionilpromazina-Meperidina en la Anestesia con Tiopental Sódico en el Caballo. (Propionylpromazine and Meperidina for premedication of Thiopentalnarcosis in the horse) $\ldots \ldots \ldots \ldots \ldots \ldots \ldots \ldots \ldots \ldots$

Dessiris, A., siehe Papadopoulos, Raptopoulos, Dessiris and Tsimopoulos . . . . . . 264

Dessiris, A., siehe auch Papadopoulos, Raptopoulos, Dessiris, Tsimopoulos and Roum-

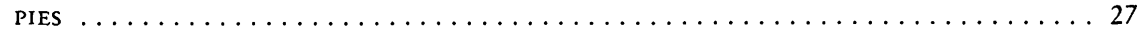

DistL, O., E. WINDISCH und H. KräUsSLICH: Zur Verbreitung und Erblichkeit der Hüftgelenksdysplasie bei den Hunderassen Hovawart und Boxer in der Bundesrepublik Deutschland. (Extension and heredity of hip displasia in Hovawart and Boxer dogs in the Federal German Republic) ...

Doll, K., D. Schillinger und W. KLeE: Der Glutaraldehyd-Test beim Rind - seine Brauchbarkeit für Diagnose und Prognose innerer Entzündungen. (The Glutaraldehyde Test in Cattle - its Usefulness for Diagnosis and Prognosis of Internal Inflammatory Conditions)

Dwenger, A., siehe HarmeYer, KnORz, Dwenger and WinkLer ............... Ederoth, Marie, siehe Lindberg, Persson, Jones, Thoren-Tolling and Ederoth . . . . . 526

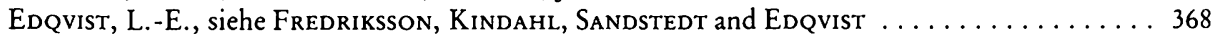

Edqvist, L.-E., siehe auch Madej, Edqvist, Kindahl and Еквонм ................ 419

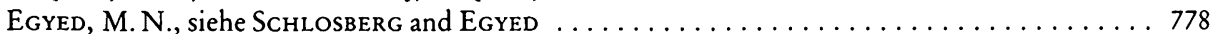

Eквонм, G., siehe Madej, EdQvist, Kindahl and Еквонм .................. 419

Ekfalck, A., B. Funkquist, B. Jones and N. Obel.: Incorporation of ${ }^{35} \mathrm{~S}$-Cystine in Tissue Fragments from the Matrix of the Bovine Claw and Effect on Incorporation Rate of Adding Blood Serum and Some Serum Fractions . . . . . . . . . . . . . . . . . . .

Eliassen, K.A., and W.ZAWAdzKI: Effects of Monensin on Polyamine Formation in Rumen

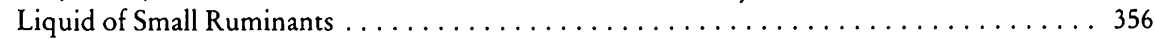

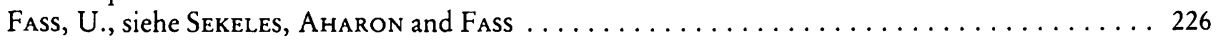

Fredriksson, G., H. Kindahl, K. SAndstedt and L.-E. Edqvist: Intrauterine Bacterial Fin-

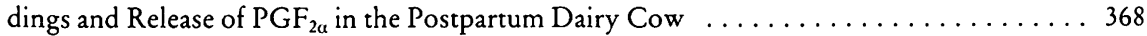

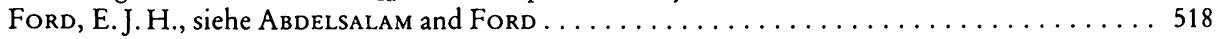

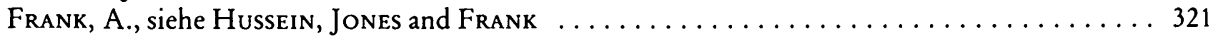

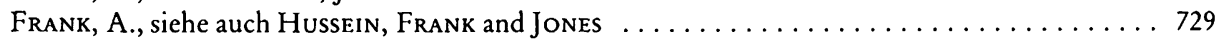

Fröhli, D., siehe Blum, Jans, Moses, Fröhli, Zemp, Wanner, Hart, Thun and Keller . . . 401

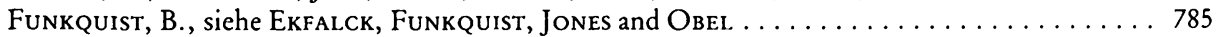

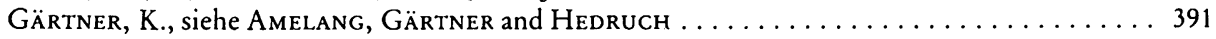

Gahlawat, J. S., siehe A. P. Singh, Jit Singh, Peshin, Gahlawat, Prem Singh and Nigam . 54

Gálfi, P., S. Neogrády, T. Veresegyházy and F. Kutas: Demonstration of Keratinizing Effect of n-Butyrate on Day-old Chicken Crop Epithelium ................ 146

García-Sacristán, A., G. Costa and A. Labadia: Sympathetic Innervation of the Urethral Muscle in Cattle . . . . . . . . . . . . . . . . . . . . . . . . . . . . 185

García-SAcristán, A., siehe auch Costa, Illera and García-SACristán . . . . . . . . 196

Gasthuys, F., A. De Moor and C. Van Den Hende: Influence of Halothane Anaesthesia, with Xylazine for Premedication, on the Calcium Concentration in the Horse . . . . . . . . . 623

Gaydarova, Kréména, siehe GÉorgiev, Gaydarova, Stanislavov et Barov $\ldots \ldots \ldots \ldots \ldots$

Gehring, W., siehe Dahir, Hild, Weyrauch und Gehring . . . . . . . . . . . . . 297

GÉorgiev, G. H., KrémÉna Gaydarova, R. Stanislavov et D. Barov: Distribution et Activité de la Nicotinamide-Adenine-Dinucléotide-Nucléosidase dans le Plasma Seminal des Mammifères. (Distribution and activity of nicotinamide adenine dinucleotide nucleosidase in

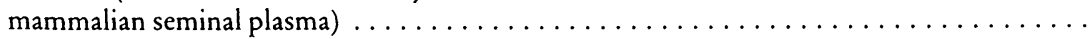

GeYer, H., P. Rüsch, L. Giese und H. Augsburger: Zur Entnahmetechnik von Euterbiopsien

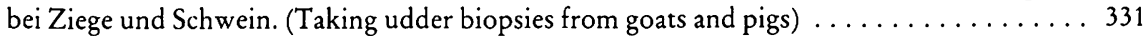

Gialamas, J., H. Höger und D. Adamiker: Akute Magendilatation und Magendrehung beim Meerschweinchen. (Acute gastric dilatation and gastric torsion in guinea-pigs) . . . . . . 772

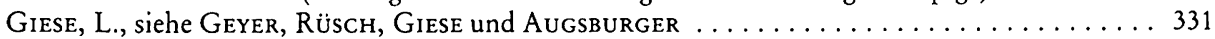

Goetze, L., siehe Vörös, Goetze, Lattmann und Scholz . . . . . . . . . . . . . . . . 110 
Greife, H.A.: Zum Einfluß der Verwertungshöhe des Futterstickstoffs auf die Verteilung einzelner N-Fraktionen im Rattenharn. (Influence of the level of utilisation of dietary nitrogen on the distribution of $\mathrm{N}$-fractions in the urine of rats) $\ldots \ldots \ldots \ldots \ldots \ldots$

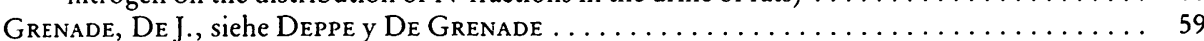

Hakkarainen, J., siehe Hassan, Jönsson and Hakkarainen $\ldots \ldots \ldots \ldots \ldots \ldots \ldots \ldots 62$

Hambitzer, R., und Antje Ruhrmann: Dialyseverfahren zur quantitativen Proteinbestimmung im Sauenharn. (Dialysis studies on quantitative protein determination in sow urine) . . . . 459

Haraszti, J., siehe Pethes, Horváth, Kulcsár, Huszenicza, Somorjai, Varga and Haraszti . . . . . . . . . . . . . . . . . . . . . . . . . . . . . . 28

HaRISCH, G., und R. SCHwARZ: Zur Biochemie der Corpora lutea periodica, der Follikel-LuteinZysten, der Nebennierenrinde und der Hypophyse des Rindes. (Contribution to the biochemistry of corpora lutea periodica, FL-cysts, Suprarenal glands and pituitary glands of

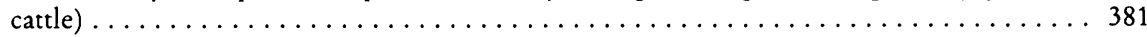

Harmeyer, J., S. Knorz, A. Dwenger and I. Winkler: The Effect of Vitamin D on the B-Cell Activity of the Endocrine Pancreas . . . . . . . . . . . . . . . . . . . . 606

Hart, I. C., siehe Blum, Jans, Moses, Fröhli, Zemp, Wanner, Hart, Thun and Keller . . . 401

Hassan, S., L. Jönsson and J. Hakkarainen: Morphological Studies on Nutritional Encephalomalacia in Chicks, with Special Reference to Mineralized Deposits in the Cerebellum . . . . 662

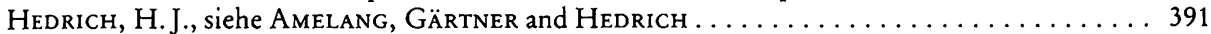

HeinRITZI, K., siehe Kirchg ESSNer, Roth, Bollwahn und HeinRITZi . . . . . . . . . . . . . . 641

Heinritzi, K., siehe auch Roth, Kirchgessner, Bollwahn und Heinritzi . . . . . . . . . . . . 652

Van Den Hende, C., siehe Gasthuys, De Moor and Van Den Hende . . . . . . . . . 623

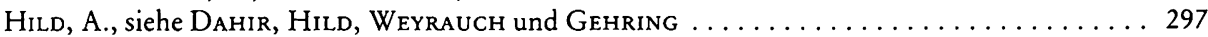

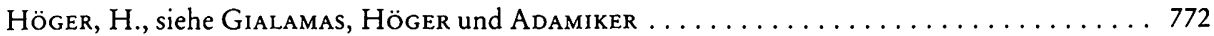

Holzmann, A., H. WÖrgöTter und F. JAHN: Der Einfluß verschiedener Lagerungstemperaturen auf die Qualität von aufgetautem Stiersamen. (Influence of different storage temperatu-

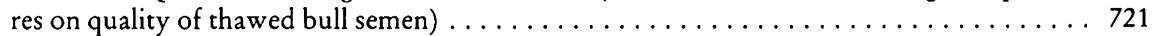

Hornstein, M., siehe Rottmann, Stratowa, Hornstein and Hughes . . . . . . . . . . 676 Horváth, E., siehe Pethes Horváth, Kulcsár, Huszemicza, Somorjai, Varga and

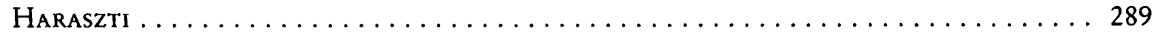

Hughes, J., siehe Rottmann, Stratowa, Hornstein and Hughes . . . . . . . . . . . . 676

Hussein, Kamal S. M., Bernt-E. V. Jones and Adrian Frank: Selenium Copper Interaction in Goats ........................................ 321

Hussein, Kamal S. M., Adrian Frank and Bernt-E. V. Jones: Influence of Intramuscular Selenium Injections on Copper Metabolism in Copper-loaded Sheep . . . . . . . . . . . . 729

Huszemicza, Gy., siehe Pethes, Harvath, Kulcsár, Huszemicza, Somorjai, Varga and Haraszti ........................................ 289

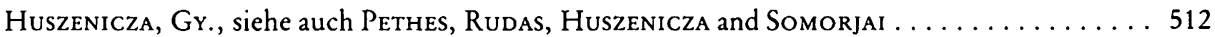

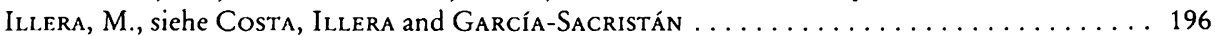

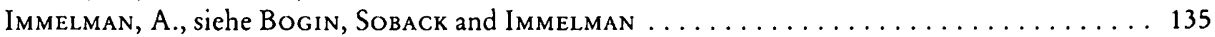

Jager, L. P., siehe van der Molen, NabuUrs and Jager $\ldots \ldots \ldots \ldots \ldots \ldots \ldots \ldots \ldots \ldots$

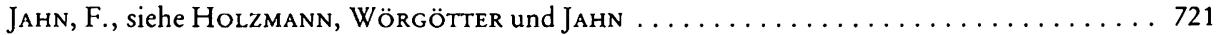

Jans, F., siehe Blum, Jans, Moses, Fröhli, Zemp, Wanner, Hart, Thun and Keller . . . . 401

Jha, G. J., siehe K. K. Singh, Jha, Chauhan and P. N. Singh . . . . . . . . . . . . 437

Jirmanová, I., and L. LojDa: Dexamethasone Applied to Pregnant Minisows Induces Splayleg

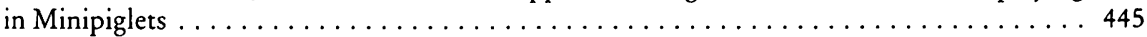

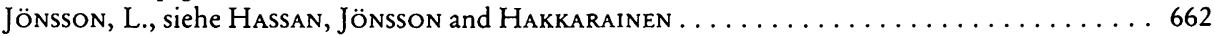

Johnsson, S., siehe Pehrson and Johnsson . . . . . . . . . . . . . . . . . . . 428

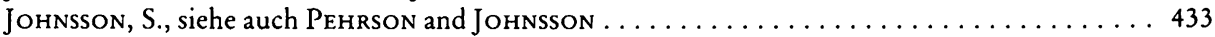

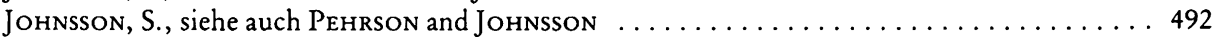

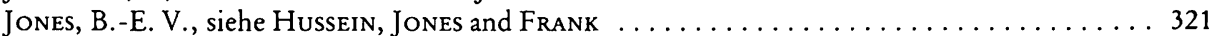

Jones, B.-E. V., siehe auch Hussein, Frank and Jones . . . . . . . . . . . . . . . . . . 729

Jones, B., siehe Lindberg, Persson, Jones, Thoren-Tolling and Ederoth . . . . . . . . 526

Jones, B., siehe auch Ekfalck, Funkquist, Jones and Obel . . . . . . . . . . . . . . 729

KaufmanN, W.: Lichtmikroskopische und ultrastrukturelle Untersuchungen zur Pathogenese der Muskelveränderungen nach Neurektomie bei wachsenden Schweinen. (Light microscopic and ultrastructural studies on the pathogenesis of muscle changes after neurectomy in

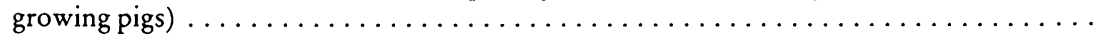

Kaufmann, W.: Histometrische und enzymhistochemische Untersuchungen zur Pathogenese der Muskelveränderungen nach Neurektomie bei wachsenden Schweinen. (Histometric 
and enzyme-histochemical studies on the pathogenesis of muscle changes after neurectomy

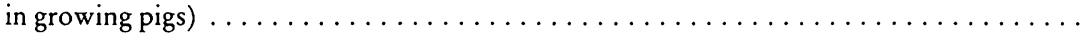

Keller, U., siehe Blum, Jans, Moses, Fröhli, Zemp, Wanner, Hart, Thun and Keller . . . 401

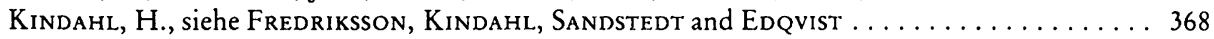

Kindahl, H., siehe auch MadeJ, Edqvist, Kindahl and Еквонм . . . . . . . . . . . 419

Kirchgessner, M., F. X. Roth, W. Bollwahn und K. Heinritzi: Mastleistung, Nährstoffverdaulichkeit und Magenschleimhautveränderungen von Schweinen bei unterschiedlicher Futterstruktur. I. Einfluß eines unterschiedlichen Vermahlungsgrades des Futters. (Fattening performance, nutrient digestibility and gastric lesions in pigs in response to a differing particle size of the feed. I. Influence of a finely and coarsely ground meal) . . . . . . . 641

Kirchgessner, M., siehe auch Roth, Kirchgessner, Bollwahn und Heinritzi . . . . . . 652

Kirchgessner, M., siehe auch Dora A. Roth-Maier, Kirchgessner und Spoerl . . . . . . . 739

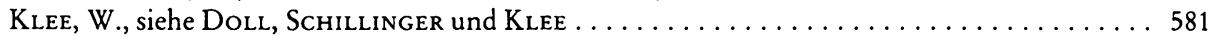

Köppel, E., Elisabeth Mayrhofer und M. Schönbauer: Schultergelenkdysplasie beim Dachshund. 2. Mitteilung: Ergebnisse der pathoanatomischen und pathohistologischen Untersuchung; Schlußfolgerungen für Rassestandard und Zucht. (Shoulder joint dysplasia in the Dachshund. 2. Pathoanatomical and pathohistological study; conclusions respecting

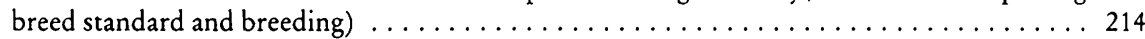

Köppel, E., siehe auch Elisabeth MAYRHOFER und Köppel $\ldots \ldots \ldots \ldots \ldots \ldots \ldots \ldots 202$

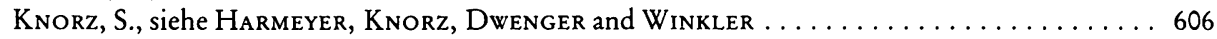

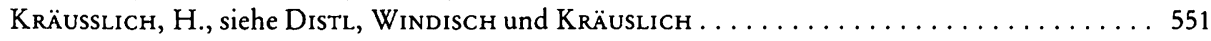

Kulcsár, M., siehe Pethes, Horváth, Kulcsár, Huszemicza, Somorjai, Varga and

Haraszti . . . . . . . . . . . . . . . . . . . . . . . . . . . . . . . . 289

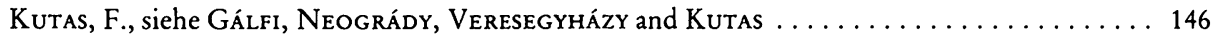

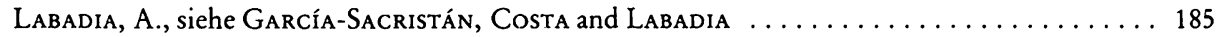

Lattmann, J., siehe Vörös, Goetze, Lattmann und Scholz . . . . . . . . . . . . . 110

Lechowski, R., siehe Degórski, Prandota, Lechowski and Miernik ............ 241

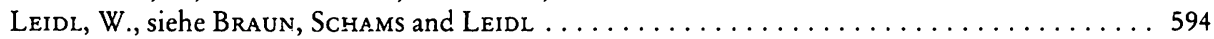

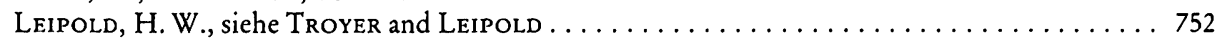

Lindberg, R., S. G. B. Persson, B. Jones, Kerstin Thoren-Tholling and Marie Ederoth: Clinical and Pathophysiological Features of Granulomatous Enteritis and Eosinophilic

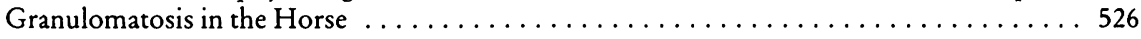

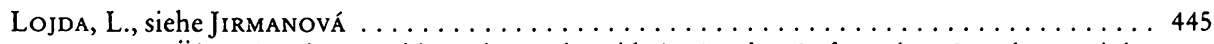

LOUPAL, G.: Über eine der Myoklonuskörperkrankheit (Morbus Lafora) des Menschen und des Hundes morphologisch ähnliche Speicherkrankheit bei einem Nymphensittich (Nymphicus bollandicus). (A storage disease in a parakeet [Nymphicus bollandicus] morphologically similar to the myoclonic systemic disease [Lafora's Disease] of man and dog) . . . . . . . 502

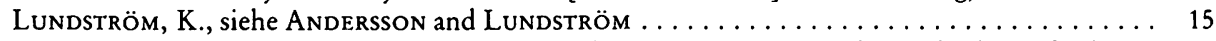

MAdej, A., L.-E. Edqvist, H. Kindahl and G. Еквонм: Circadian Rhythm of Plasma Prolactin in Heifers ................................. 419

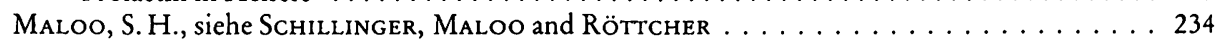

Mann, A., A. Pospischil und E. Dahme: Der Plexus submucosus (Meissner) beim Kalb. II. Licht- und elektronenmikroskopische Untersuchung nach Monoinfektionen bzw. Mischinfektionen mit Rotaviren und enterotoxischen E. coli. (The plexus submucosus [MEISSNER] in the calf. II. Light and electronmicroscopic study after monoinfection and

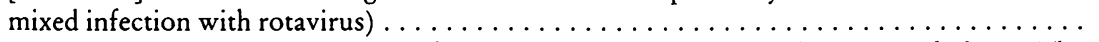

Martens, H.: Magnesium Absorption from the Temporarily Isolated Rumen of Sheep. The

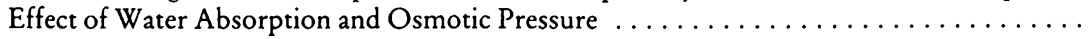

Mayrhofer, Elisabeth, und E. Köppel: Schultergelenkdysplasie beim Dachshund. 1. Mitteilung: Klinik und Röntgenbefunde. (Shoulder joint dysplasia in the Dachshund. 1. Clinical

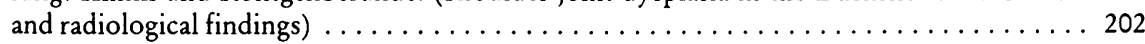

Mayrhofer, Elisabeth, siehe auch Köppel, Elisabeth Mayrhofer und Schönbauer . . . . . 214

Medeiros, L. F., L. O. Medeiros, R. Nürmberger Junior and F. R. A. Perdigão de OliVEIRA: Energy Metabolism in the Erythrocytes of Donkeys .............. 483

Medeiros, L.O., siehe auch Medeiros, L.F., L. O. Medeiros, Nürmberger Junior and

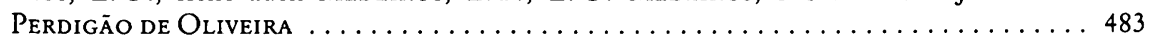

Michelmann, H. W., siehe Heidrun Schniedewind, Michelmann und Paufler . . . . . . 31

Miernik, E., siehe Degórski, Prandota, Lechowski and Miernik . . . . . . . . . . 241

Möstl, H. S., siehe Bamberg, Choi, Möstl und Scharf . . . . . . . . . . . . . . . 119

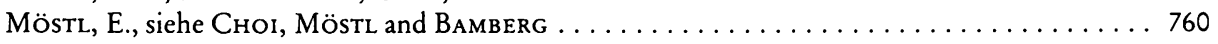


Van der Molen, E. J., M. J. A. Nabuurs and L. P. Jager: Pathological and Clinical Changes related to Toxicity of Carbadox in Weaned Pigs ........................ 540

De Moor, A., siehe Gasthuys, De Moor and Van Den Hende ............... 623

Moses, W., siehe Blum, Jans, Moses, Fröhli, Zemp, Wanner, Hart, Thun and Keller . . . 401

Mostaghni, K.: A Study of Bile Secretion in Conscious Sheep . . . . . . . . . . . 75

Moudgal, R. P., and M. N. Razdan: In vitro Studies on Ovulatory Mechanisms in the Hen ... 179

Moudgal, R.P., and M. N. Razdan: Catecholamines in Different Areas of Brain During the Ovulatory Cycle in the Hen and their Relationship to Egg Traits

Munsel, M., und S. Paufler: Histometrische Untersuchungen des Genitaltraktes beim Kaninchen in der postpartalen Phase. (Histometric studies of the genital tract of the rabbit in the

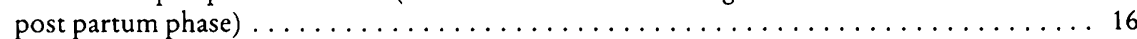

Muylle, E., siehe Nuytten, Muylle and Oyaert $\ldots \ldots \ldots \ldots \ldots \ldots \ldots \ldots \ldots \ldots \ldots \ldots$

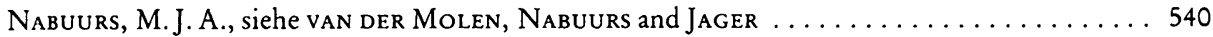

Neogrády, S., siehe Gálfi, Neogrády, Veresegyházy and Kutas . . . . . . . . . . . . 146

Niezgoda, J., siehe Pierzchala, Niezgoda and Bobek ................... 140

Nigam, J. M., siehe A. P. Singh, Jit Singh, Peshin, Gahlawat, Prem Singh and Nigam … 54

Nürmberger Junior, R., siehe L.F. Medeiros, L. O. Medeiros, Nürmberger Junior and Perdigão de Oliveira . . . . . . . . . . . . . . . . . . . . . . . . . 483

Nuytten, J., E. Muylle and W. Oyaert: Pulmonary Haemodynamics in Healthy Calves and in Calves Suffering from Respiratory Disorders $\ldots \ldots \ldots \ldots \ldots \ldots \ldots \ldots \ldots \ldots . \ldots \ldots$

Obel, N., siehe Ekfalck, Funkquist, Jones and Obel .................... 785

Овг, T. U.: Casein-Induced Anaphylactic-Type acute Respiratory Distress Syndrome in Calves . 43

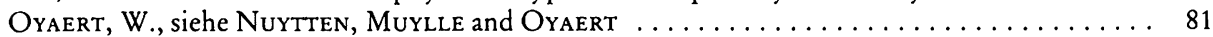

Papadopoulos, Ph., D. Raptopoulos, A. Dessiris and G. Tsimopoulos: Experimental Intestinal Obstruction in Cattle. Part I: Changes in the clinical picture . . . . . . . . . . 264

Papadopoulos, Ph., D. Raptopoulos, A. Dessiris, G. Tsimopoulos and N. Roumpies: Experimental Intestinal Obstruction in Cattle. Part II: Changes in blood, urine and rumen

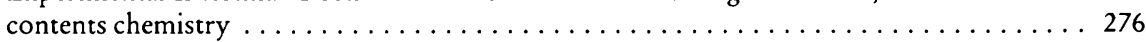

Paufler, S., siehe Heidrun Schniedewind und Paufler $\ldots \ldots \ldots \ldots \ldots \ldots \ldots \ldots \ldots \ldots \ldots$

Paufler, S., siehe auch Heidrun Schniedewind, Michelmann und Paufler $\ldots \ldots \ldots \ldots \ldots$.

Pehrson, B., and S. Johnsson: Selenium and glutathione peroxidase in blood and tissues and growth and feed efficiency in young bulls at different dietary selenium levels . . . . . . 492

Pehron, B.: Selenium-dependent and non-selenium-dependent glutathione peroxidase activity

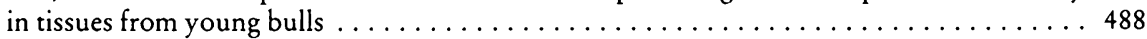

Pehronon, B., and S. Johnsson: Addition of selenium to beef cattle given a selenium-deficient

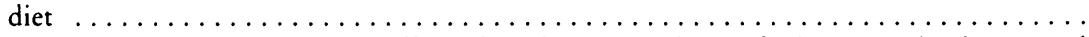

Pehroson, B., and S. Johnsson: The effect of single, peroral doses of selenium in beef cows and

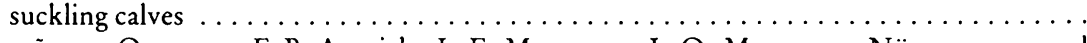

Perdigño de Oliveira, F. R. A., siehe L. F. Medeiros, L. O. Medeiros, Nürmberger and

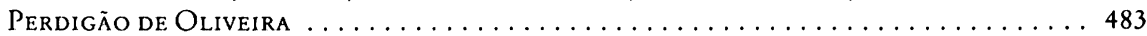

Persson, S. G. B., siehe Lindberg, Persson, Jones, Thoren-Tolling and Ederoth . . . . 526

Peshin, P. K., siehe A. P. Singh, Jit Singh, Peshin, Gahlawat, Prem Singh and Nigam . . . 54

Pethes, G., E. Horváth, M. Kulcsár, Gy. Huszenicza, Gy. Somorjai, B. Varga and J. Harasztr: In Vitro Progesterone Production of Corpus Luteum Cells of Cows Fed Low and High Levels of Beta-Carotene .......................... 28

Pethes, G., P. Rudas, Gy. Huszenicza and Gy. Somorjal: Conversion of Thyroxine to Triiodothyronine in Liver Biopsy Samples of Beta-Carotene and Vitamin-A Supplemented

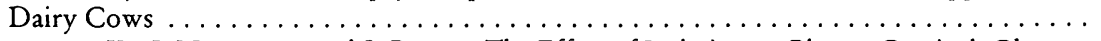

Pierzchata, K., J. Niezgoda and S. Bobek: The Effect of Isolation on Plasma Cortisol, Glucose

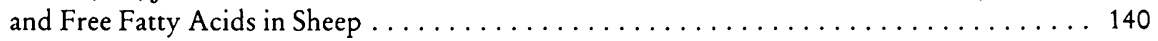

Pierzynowski, S., siehe Debski and Pierzynowski $\ldots \ldots \ldots \ldots \ldots \ldots \ldots \ldots \ldots \ldots \ldots \ldots \ldots \ldots \ldots \ldots$

Pospischil, A., siehe Maria T. Stigmair-Herb und Pospischil . . . . . . . . . . . . . . . . . 249

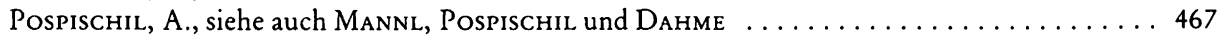

Pospischil, A., siehe auch Maria Stiglmair-Herb und Pospischil . . . . . . . . . . . . . 764

Prandota, J., siehe Degórski, Prandota, Lechowski and Miernik ............... 241

Raptopoulos, D., siehe Papadopoulos, Raptopoulos, Dessiris and Tsimopoulos . . . . . 264

Raptopoulos, D., siehe auch Papadopoulos, Raptopoulos, Dessiris, Tsimopoulos and

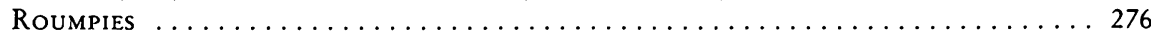

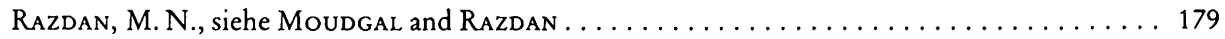

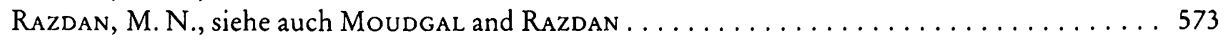


RicnÝ, J., siehe Tucek, Svoboda, RicnÝ, Bass, Soukup and VITEK .............. 1

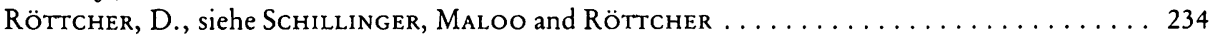

Roth, F. X., M. Kirchgessner, W. Bollwahn und K. Heinritzi: Mastleistung, Nährstoffverdaulichkeit und Magenschleimhautveränderungen von Schweinen bei unterschiedlicher Futterstruktur. II. Einfluß eines Zusatzes von Na-Polyacrylat und grober Haferschälkleie. (Fattening performance, nutrient digestibility and gastric lesions in pigs in response to a differing particle size of the feed. II. Influence of a supplement of sodium polyacrylate and

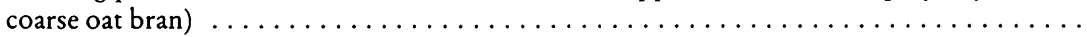

Roth, F. X., siehe auch Kirchgessner, Roth, Bollwahn und Heinritzi . . . . . . . . 641

Roth-Maier, Dora A., M. Kirchgesser und R. Spoerl: Fe-Bilanzen gravider und laktierender Zuchtsauen bei unterschiedlicher alimentärer Eisenzufuhr. (Fe-balances of gravid and lactating sows with varying dietary iron supply) $\ldots \ldots \ldots \ldots \ldots \ldots \ldots \ldots \ldots \ldots$

Rottmann, O. J., Chr. Stratowa, M. Hornstein and J. Hughes: Tissue Specific Expression of Hepatitis B Surface Antigen in Mice Following Liposome - Mediated Gene Transfer

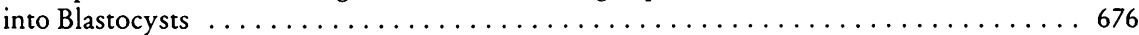

Roumpies, N., siehe Papadopoulos, Raptopoulos, Dessiris, Tsimopoulos and Roumpies . 276

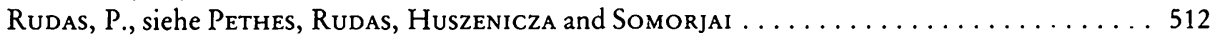

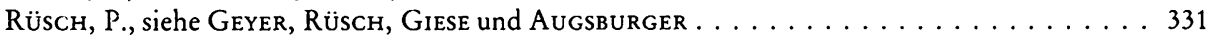

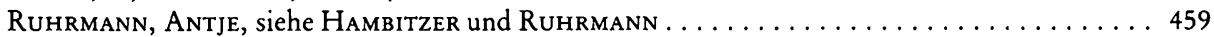

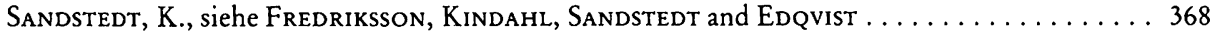

Schams, D., siehe Braun, Schams and Leidl ............................ 594

Scharf, A., siehe Bamberg, Choi, Möstl und Scharf . . . . . . . . . . . . . . . . 119

SCHIllinger, D., S. H. Maloo and D. Rötrcher: The Toxic Effect of Intravenous Application

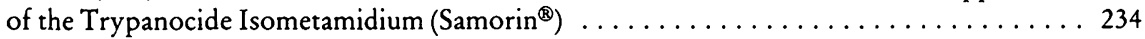

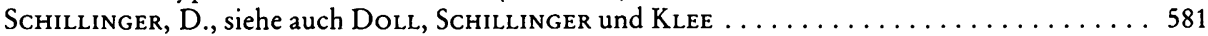

Shlosberg, A., and M. N. Egyed: Experimental Ferula communis (giant fennel) Toxicosis in Sheep ............................................ 778

SChnifdriwind, Heidrun, und S. Paufler: Die Meiose-Chromosomen der Regenbogenforelle (Salmo gairdneri). (Meiotic chromosomes of the rainbow-trout [Salmo gairdneri]) .......

Schniedewind, Heidrun, H. W. Michelmann und S. Paufler: Die Mitose-Chromosomen der Regenbogenforelle (Salmo gairdneri). (Mitotic chromosomes of the rainbow-front

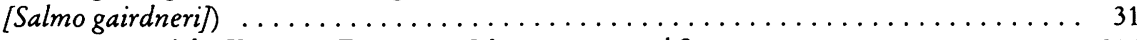

Schönbauer, M., siehe Köppel, Elisabeth Mayrhofer und Schönbauer . . . . . . . . 214

Scholz, H., siehe Vörös, Goetze, Lattmann und Scholz $\ldots \ldots \ldots \ldots \ldots \ldots \ldots \ldots \ldots \ldots$

Schopper, D., siehe Claus, Schopper, Wagner and Weiler $\ldots \ldots \ldots \ldots \ldots \ldots \ldots \ldots \ldots$

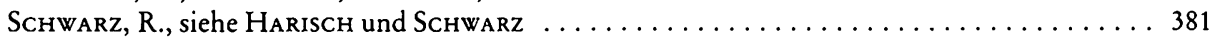

Sekeles, E., D. C. Aharon and U. Fass: Carniofacial Duplication (Diprosopus) in the Cat Case Report and Review of the Literature . . . . . . . . . . . . . . . . 226

Sekeles, E.: Posterior duplication (cephalothoracopagus syncephalus) in the cat. (Case, review

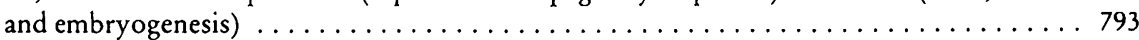

Singh, A.P., Jit Singh, P. K. Peshin, J.S. Gahlawat, Prem Singh and J. M. Nigam: Evaluation of Xylazine-Ketamine Anaesthesia in Buffaloes (Bubalus bubalis) ..........

Singh, Jit, siehe A. P. Singh, Jit Singh, Peshin, Gahlawat, Prem Singh and Nigam ......

Singh, K. K., G. J. Jha, H. V.S. Chauhan and P. N. Singh: Pathology of Chronic Aldrin Intoxication in Goats . . . . . . . . . . . . . . . . . . . 437

Singh, Prem, siehe A. P. Singh, Jit Singh, Peshin, Gahlawat, Prem Singh and Nigam . . 54

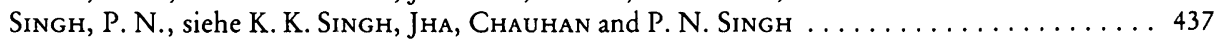

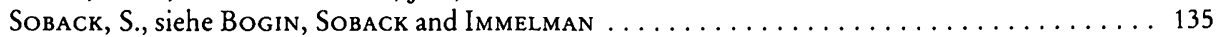

Somorjai, Gy., siehe Pethes, Horváth, Kulcsár, Huszemicza, Somorjai, Varga and

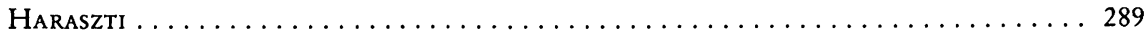

Somorjai, Gy., siehe auch Pethes, Rudas, Huszenicza and Somorjai . . . . . . . . . . . 512

Soukup, T., siehe Tucek, Svoboda, Ricný, Bass, Soukup and Vitek . . . . . . . . . . . 1

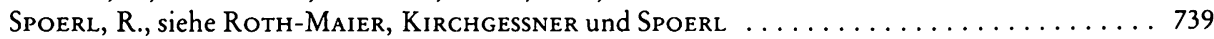

Stanislavov, R., siehe GÉorgiev, Gaydarova, Stanislavov et Barov $\ldots \ldots \ldots \ldots \ldots \ldots . \quad 11$

Stiglmair-Herb, Maria T., und A. Pospischil: Eine neue Methode zur Auswertung enzymhistochemischer Untersuchungen der Darmschleimhaut erläutert am Beispiel gesunder und erkrankter Kälber. (A new method for the analysis of intestinal enzyme histochemistry. A

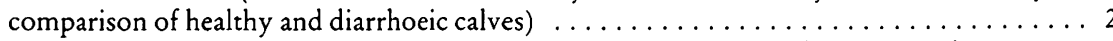

Stiglmair-Herb, Maria T., und A. Pospischil: Enzymhistochemische Untersuchungen am Darmepithel von Hunden nach Kasein-Diät, Single Cell Protein-Diät und konventioneller 
Fütterung. (Enzyme histochemical investigations of the intestinal epithelium in dogs on diets containing casein or single cell protein compared to conventionally reared animals) . . 764

Stratowa, Ch., siehe Rottmann, Stratowa, Hornstein and Hughes . . . . . . . . . . 676

Svoboda, T., siehe Tuček, Svoboda, Ríčny, Bass, Soukup and Vítek ............. 1

TEMPEL, K.: DNA-Reparaturvorgänge in Thymus- und Milzzellen der Ratte in vitro unter dem Einfluß des Poly(ADP-ribose)-Polymerase-Hemmstoffs 3-Aminobenzamid. (DNA-reparative changes in thymus and spleen cells of rats in vitro under the influence of poly(ADP-

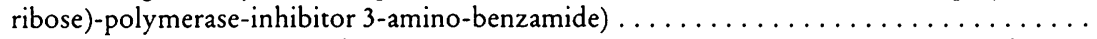

Thoren-Tolling, Kerstin, siehe Lindberg, Persson, Jones, Thoren-Tolling and Ede-

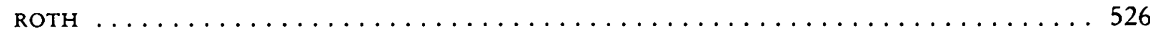

Thun, R., siehe Blum, Jans, Moses, Fröhli, Zemp, Wanner, Hart, Thun and Keller . . . 401

Troyer, D., and H.W. Leipold: Rectovaginal Constriction in Jersey Cattle. (I. Cross Anatomical Studies) ................................. 752

Tsimopoulos, G., siehe Papadopoulos, Raptopoulos, Dessiris and Tsimopoulos . . . . . . 264

Tsimopoulos, G., siehe auch Papadopoulos, Raptopoulos, Dessiris, Tsimopoulos and

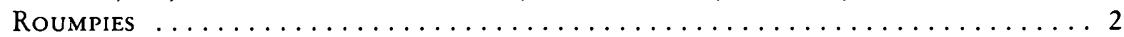

TuČek, S., T. Svoboda, J. RíčnÝ, A. Bass, T. Soukup and V. Vítek: The Concentration of Choline and the Activities of Cholinesterase, Creatine Kinase and Lactate Dehydrogenase in the Blood Plasma of Piglets with the Syndrome of Splayleg (Congenital Myofibrillar

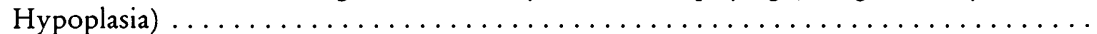

Varga, B., siehe Pethes, Horvath, Kulcsár, Huszemicza, Somorjai, Varga and Haraszti Veresegyházy, T., siehe Galfi, Neogrády, Veresegházy and Kutas . . . . . . . . . . . . . 146

Vitek, V., siehe Tuček, Svoboda, RíčnÝ, Bass, Soukup and Vítek . . . . . . . . . . . . Vörös, K., L. Goetze, J. Lattmann und H. Scholz: Serumelektrolyte und Parameter des Säurebasenhaushaltes in Blut und Harn bei an Labmagenverlagerung erkrankten Kühen (unter Berücksichtigung des Refluxsyndromes). (Serum electrolytes and parameters of acide-base content of blood and urine in cows with abomasal displacement [with considera-

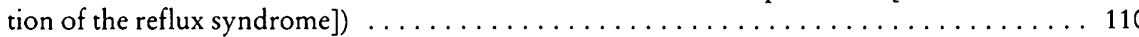

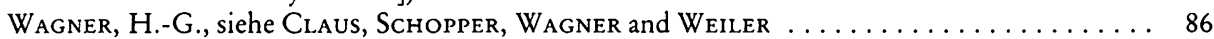

Wagner, H.-G., siehe auch Claus, Weiler and Wagner .................. 99

Wanner, M., siehe Blum, Jans, Moses, Fröhl, Zemp, Wanner, Hart, Thun and Keller . . 401

Weiler, U., siehe Claus, Schopper, Wagner and Weiler $\ldots \ldots \ldots \ldots \ldots \ldots \ldots \ldots \ldots$

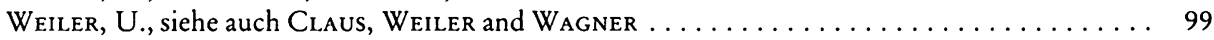

Wensing, Th., siehe van Beukelen, Wensing and Breuking . . . . . . . . . . . . 561

Weyrauch, K. D., siehe Dahir, Hild, Weyrauch und Gehring . . . . . . . . . . . . . . . . . 297

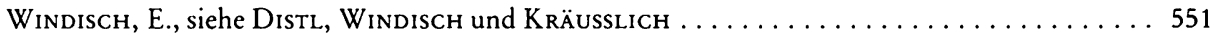

WINKLER, I., siehe HARMEYER, KNORZ, DWENGER and WINKLER ............... 606

Wittenberger, C.: Influence of Hypothermia on the Carbohydrate Tissue Metabolism in

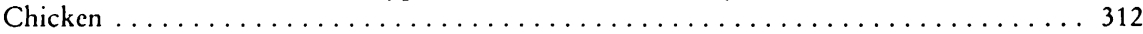

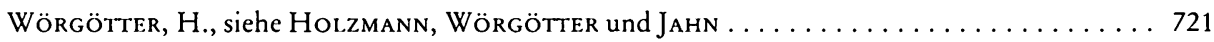

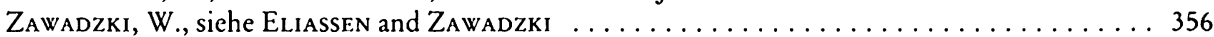

Zemp, M., siehe Blum, Jans, Moses, Fröhli, Zemp, Wanner, Hart, Thun and Keller .... 401

\section{Kurze Mitteilungen/Short Communications}

Chadli, M., siehe Mahin, Chadli, Marzou, MaAch and Ychou .............. 151

GäBEL, G., and H. MARTENS: Magnesium Absorption from the Rumen of Heifers . . . . . . . 636

Harisch, G., and R. MüLler: The Glutathione Redox System in the Rat Liver after Administra-

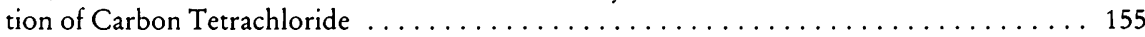

MaAch, L., siehe Mahin, Chadli, Marzou, MaAch and Ychou .............. 151

Mahin, L., M. Chadli, A. Marzou, L. MaAch and M. Ychou: Differences in Coagulability of

Three Glutaraldehyde Solutions in the Glutaraldehyde Test on Bovine Whole Blood . . . . 151

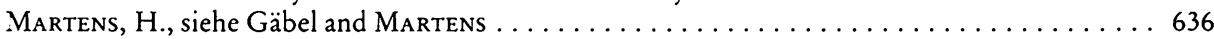

Marzou, L., siehe Mahin, Chadli, Marzou, MaAch and Ychou . . . . . . . . . . . . 151

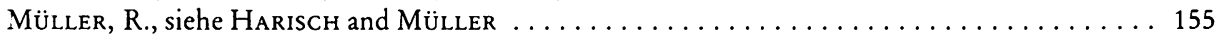

Ychou, M., siehe Mahin, Chadli, Marzou, MaAch and Ychou ............... 151 


\section{Buchbesprechungen / Book Reviews}

Berchtold, M., und E. Grunert: Tierärztliche Geburtshilfe und Gynäkologie in Frage und

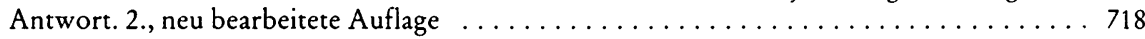

Bogner, H., und A. Grauvogel (eds.): Verhalten landwirtschaftlicher Nutztiere . . . . . . . 720

Dietz, O., F. Schaetz, H. Schleiter und R. Teuscher: Anaesthesie und Operationen bei Groß- und Kleintieren. 3., unveränderte Auflage . . . . . . . . . . . . . . . . . 640

Drochner, W.: Einfluß wechselnder Rohfaser- und Pektingehalte im Futter auf einige praecaecale und postileale Verdauungsvorgänge beim wachsenden Schwein. „Fortschritte in der

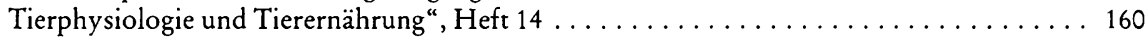

Elze, K., H. Meyer, G. Steinbach und Th. Hiepe: Jungtierkrankheiten. 2., überarbeitete und erweiterte Auflage . .................................... 719

Grunert, E. (Hrsg.): BUIATRIK, Band I, Euterkrankheiten, Geburtshilfe und Gynäkologie,

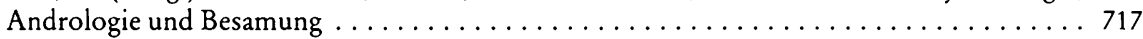

Horzinek, Marian C.: Kompendium der allgemeinen Virologie. Pareys Studientexte Nr. 4. 2., neubearbeitete Auflage . . . . . . . . . . . . . . . . . . . . . . . . . . . . . . . . . 480

Journal of Applied Ichthyology. Zeitschrift für angewandte Ichthyologie $\ldots \ldots \ldots \ldots \ldots \ldots 718$

Kielwein, G.: Leitfaden der Milchkunde und Milchhygiene. 2., neubearbeitete Auflage. Pareys

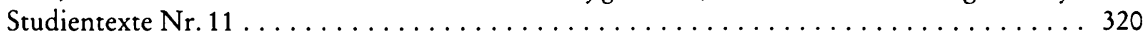

Mayr, A., G. Eissner und Barbara Mayr-Bibrach: Handbuch der Schutzimpfungen in der Tiermedizin . . . . . . . . . . . . . . . . . . . . . . . . . . . . . . . . . 399

Neue Erkenntnisse über die Erreger bakterieller Lebensmittel-Infektionen. Heft 14 der Schriftenreihe der Schweizerischen Gesellschaft für Lebensmittelhygiene (SGLH) . . . . . . . 240

Nickel/Schummer/Seiferle: Lehrbuch der Anatomie der Haustiere. Bd. I: Bewegungsapparat. 5., überarb. Aufl. . . . . . . . . . . . . . . . . . . . . . . . . . . . 80

OTt, J. A., G. P. WAGNER und F. M. Wuketits (Hrsg.): Evolution, Ordnung und Erkenntnis . 719

RiecK, G. W., und K. Zerobin: Zuchthygiene Rind. Pareys Studientexte Nr. $46 \ldots \ldots \ldots \ldots .719$

Roberts, R. J., und H.-J. Schlotfeldt: Grundlagen der Fischpathologie . . . . . . . . . 800

Sandersleben, J. von, K. Dämmerich und E. Dahme: Pathologische Histologie der Haustiere. 240

Schebitz, H., und W. Brass: Operationen an Hund und Katze . . . . . . . . . . . . . . . 717

WieSNER, E., und S. WILleR: Lexikon der Genetik der Hundekrankheiten . . . . . . . . . . . . . . 399 


\title{
Der Glutaraldehyd-Test beim Rind - seine Brauchbarkeit für Diagnose und Prognose innerer Entzündungen
}

\author{
Von K. Doll, D. Schillinger und W. KleE \\ Adresse der Autoren: II. Medizinische Tierklinik, Veterinärstr. 13, D-8000 München 22
}

Mit 6 Tabellen

(Eingegangen am 24. November 1984)

Die Erkennung innerer Entzündungen sowie ihre prognostische Beurteilung bereiten dem Untersucher nicht selten erhebliche Schwierigkeiten, insbesondere wenn sich der Prozeß bereits in einem chronischen Stadium befindet. Da sich auf dem Wege der klinischen Untersuchung zwar in der Regel ein Verdacht äußern, oft jedoch keine sichere Diagnose stellen läßt, wird man in solchen Fällen bestrebt sein, weiterführende Laboruntersuchungen zur Klärung heranzuziehen. Gefragt sind vor allem Tests, die sich auch in der tierärztlichen Landpraxis einfach und schnell durchführen lassen.

Außer in Blutbildveränderungen zeigen sich infektiös-entzündliche Krankheiten auch in Verschiebungen des Plasma-Fibrinogenspiegels und der Serum-Eiweißfraktionen. Wenn auch die einzelnen Plasmaproteine keine pathognomonischen Hinweise auf eine bestimmte Krankheit liefern $(15,20,27)$, so geben sie doch Aufschluß über die Intensität und das Stadium einer Entzündung (14). Bereits innerhalb von 24 Stunden nach der Einwirkung einer entzündungsauslösenden Noxe kommt es zu einem initialen Fibrinogenanstieg (19). Der Höhe und dem Verlauf der Fibrinogenwerte wird diagnostische und prognostische Bedeutung beigemessen $(3,5,13,14,19,25)$. Von den Serumproteinen nehmen in der akuten Phase ciner Entzündung zunächst die $\alpha$ - und $\beta$-Globulinfraktion $(12,15,20) \mathrm{zu}$, während im weiteren Verlauf die $\gamma$-Globuline dominieren $(3,11,12,14,15)$. Hyperproteinämien werden, wenn keine Dehydratation vorliegt, bei kranken Rindern als Anzeichen einer subakuten oder chronischen Entzündung bewertet $(2,9)$.

Außer mittels elektrophoretischer Bestimmung versucht man mit den schon lange bekannten „Eiweißlabilitätsproben“ Veränderungen in der Konzentration der verschiedenen Serumproteine zu erfassen. Unter diesen Tests, die überwiegend aus der Humanmedizin stammen und eine deutliche Beziehung zum $\gamma$-Globulingehalt erkennen lassen, konnte beim Rind nur die Formolgel-Probe nach Gaté und PAPACOSTAS eine gewisse Bedeutung erlangen $(10,13,14,15)$. Zur Testdurchführung ist allerdings Serum erforderlich, und die Reaktionszeit beträgt bis zu 24 Stunden. Das sind Bedingungen, die ihren Wert als praxisnahen Schnelltest erheblich einschränken. Auch wird das Fibrinogen, dem gerade beim Rind eine erhebliche Bedeutung im Entzündungsgeschehen zukommt $(19,26)$, nicht miterfaßt.

Der von SANDholm entwickelte Glutaraldehyd-Test $(23,24)$ brachte hier durch die Verwendung von Vollblut bei wesentlich kürzeren Reaktionszeiten einen deutlichen Fortschritt. Glutardialdehydlösungen niedriger Konzentration führen bei bestimmten 
Proteinen - in Abhängigkeit von der Anzahl und der strukturellen Anordnung ihrer basischen Aminosäurereste - zur intermolekularen Vernetzung und damit zu einer Gelbildung des Reaktionsgemisches $(7,8,22)$. Von den im Rinderplasma vorhandenen Proteinmolekülen reagieren mit einer verdünnten Glutardialdehydlösung fast ausschließlich das Fibrinogen und die $\gamma$-Globuline $(23,24)$. Versetzt man Vollblut mit einer $1,2 \%$ igen Glutardialdehydlösung, der zur Verhinderung der Blutgerinnung $1 \mathrm{mg}$ $\mathrm{Na}_{2}$ EDTA/ml $(23,24)$ zugesetzt werden', besteht eine signifikante Korrelation zwischen dem Eintritt der Koagulation des Reaktionsgemisches und der Höhe des Fibrinogen- und $\gamma$-Globulingehaltes der Blutprobe $(13,14,15,16,18,23,24)$.

In der vorliegenden Arbeit sollte vor allem die bei der praktischen Anwendung interessierende Frage nach dem diagnostischen und prognostischen Aussagewert des Testergebnisses untersucht werden.

\section{Material und Methodik Versuchstiere}

In der retrospektiven Studie wurden die Daten von 433 Klinikpatienten aus den Jahren 1982 und 1983 ausgewertet, bei denen im Rahmen der klinischen Untersuchung der Glutaraldehyd-Test durchgeführt worden war.

Rassenverteilung: DFV 289 (66,8\%), DSB 84 (19,4\%), DBV 33 (7,6\%), DRB 10 (2,3\%), Kreuzungstiere $17(3,9 \%)$.

Geschlecht: $418(96,5 \%)$ weiblich, $15(3,5 \%)$ männlich.

Alter: 1 bis $\leq 3$ Jahre $134(31,0 \%),>3$ bis $\leq 6$ Jahre $197(45,5 \%),>6$ bis $\leq 9$ Jahre $85(19,6 \%)$, über 9 Jahre $17(3,9 \%)$.

Erkrankungsdauer vor dem ersten Test (laut Vorbericht): Bis zu 3 Tagen 124 (28,6\%), bis zu 1 Woche 109 (25,2\%), bis zu 2 Wochen 108 (24,9\%), länger als 2 Wochen $92(21,3 \%)$.

Junge Rinder haben bis etwa zum Ende des ersten Lebensjahres einen verhältnismäßig niedrigen Serum-Globulinspiegel, der sich auch unter dem Einfluß einer schweren Entzündung nicht so erhöht, daß der Glutaraldehyd-Test aussagekräftige Ergebnisse liefert (16). Aus diesem Grunde wurden alle Tiere, die jünger als ein Jahr waren, in dieser Kasuistik nicht berücksichtigt. Bei 114 Tieren war der Test nach durchschnittlich zwei bis drei Tagen wiederholt, bei 28 Rindern auch ein drittes Mal durchgeführt worden.

Art der Erkrankungen (Tab. 1): Bei 296 Rindern (68,4\%) lagen primär infektiös-entzündliche Krankheitsprozesse vor. Vergleichend dazu wurde der Test auch bei 135 Tieren (30,9\%) mit nichtentzündlichen Primärleiden durchgeführt, jedoch ist zu berücksichtigen, daß bei etwa der Hälfte (64) der Patienten dieser Gruppe lokale Entzündungen als Nebenbefunde festgestellt wurden. Bei 3 Rindern $(0,7 \%)$ erwies sich trotz des auf eine Krankheit hindeutenden Vorberichts das Allgemeinbefinden als ungestört.

Insgesamt konnte bei 404 Tieren der Krankheitsverlauf und, soweit sie aus der Klinik wieder nach Hause entlassen werden konnten, auch die weitere Entwicklung über den anschließenden Zeitraum von zwei Monaten in Erfahrung gebracht werden. Als geheilt wurden nui solche Tiere angesehen, die diese Zeitspanne bei gutem Allgemeinbefinden und ohne Rezidivieren der ursprünglichen Symptome überstanden.

\section{Ausfübrung des Glutaraldehyd-Tests}

Die für den Test benutzte Flüssigkeit bestand aus einer 1,25\%igen Glutardialdehydlösung, die wie folgt hergestellt wurde: $50 \mathrm{ml}$ einer $25 \%$ igen Glutardialdehydlösung ${ }^{2}$ wurden zusammen mit 1 Gramm $\mathrm{Na}_{2}$-EDTA in 1 Liter physiologischer Kochsalzlösung gelöst. Um eine Oxidation zu vermeiden, erfolgte die Aufbewahrung lichtgeschützt in einer dunklen Glasflasche. Zur Testdurchführung wurden $2 \mathrm{ml}$ der Lösung in ein Polystyrolröhrchen pipettiert und die gleiche Menge gerinnungsgehemmtes Blut hinzugegeben (aus Einmal-Blutentnahmeröhrchen mit $\mathrm{K}_{2}$-EDTAZusatz). Teilweise wurde auch die Testflüssigkeit in einer Einmalspritze $(5 \mathrm{ml})$ vorgelegt und die

\footnotetext{
${ }^{1}$ Ein Fertigtest, der bereits die entsprechende Menge Testflüssigkeit in speziellen Reaktionsgefäßen enthält, ist unter dem Namen Glutarsel-Test ${ }^{\circledR}$ (Fa. Selectavet) im Handel.

${ }^{2}$ Glutardialdehydlösung 25\%ig für die Elektronenmikroskopie, Fa. Merck, Art. 4329.
} 
Tabelle 1

Art und Verteilung der Krankheiten bei den getesteten Rindern

\begin{tabular}{|c|c|c|c|}
\hline Entzündliche Erkrankungen & $\begin{array}{l}\text { Anzahl } \\
296 \\
(68,4 \%)\end{array}$ & Nichtentzündliche Erkrankungen & $\begin{array}{l}\text { Anzahl } \\
134 \\
(30,9 \%)\end{array}$ \\
\hline Reticuloperitonitis traumatica & 57 & Labmagenverlagerung & 49 \\
\hline Peritonitis & 45 & Blinddarmdilatation & 12 \\
\hline Endokarditis, Perikarditis & 23 & Pansentympanie, & \\
\hline Bronchopneumonie & 21 & funktionelle Stenose & 7 \\
\hline Nephritis, Pyelonephr., Zystitis & 19 & Sonstige Labmagen- & \\
\hline Hepatitis apost., Hepatitis fasc. & 6 & Darmerkrankungen & 12 \\
\hline Endometritis & 5 & Stoffwechselstörungen & 14 \\
\hline Labmagenulzera & 4 & Leberdegeneration, & \\
\hline Darmentzündungen, einschl. & & Leberstauung, Gallenstauung & 15 \\
\hline MDW-Befall & 18 & Lungenemphysem, & \\
\hline Entzündl. Erkrankungen des & & Subkutanes Emphysem & 9 \\
\hline Bewegungsapparats & 39 & Tumoren & 5 \\
\hline Euterentzündungen & 15 & Vergiftungen & 4 \\
\hline Äußere Abszesse und Phlegmonen & 15 & Zentralnervöse Störungen & 3 \\
\hline Aktinobazillose, Aktinomykose & 6 & Anämie, Hämatom & 3 \\
\hline Photosensibilitätsreaktion, & & Angeborener Herzfehler & 1 \\
\hline Euter-Schenkel-Dermatitis & 4 & & \\
\hline Enzephalitis, Meningitis & 6 & & \\
\hline Allgem. Infektionskrankheiten & 13 & & \\
\hline
\end{tabular}

Ungestörtes Allgemeinbefinden 3 Tiere $(0,7 \%)$

entsprechende Blutmenge bei Punktion der Vena jugularis über die Kanüle direkt aufgezogen. Durch mehrmaliges Kippen wurden Blut und Testflüssigkeit gemischt und das Gemisch nach Ablauf von jeweils einer Minute durch Neigung des Reaktionsgefäßes auf Eintritt der Koagulation geprüft.

\section{Vergleichende Untersuchungen und statistische Berechnungen}

Die Ergebnisse des Glutaraldehyd-Testes wurden mit dem Serum-Eiweißgehalt ${ }^{3}$, dem $\gamma$-Globulingehalt ${ }^{+}$und dem Fibrinogengehalt ${ }^{5}$ verglichen. Außerdem wurde überprüft, inwieweit sich das Alter und die Erkrankungsdauer vor dem ersten Test auf die Reaktionszeit auswirken (Regressionsanalyse) und ob bei schweren inneren Entzündungen das Testergebnis bei Wiederholung durch den Krankheitsverlauf beeinflußt wird ( $t$-Test).

Zur Definierung des Aussagewertes der Testergebnisse wurden für die verschiedenen Krankheitsgruppen folgende Maßzahlen berechnet $(4,28)$ :

- Diagnostische bzw. prognostische Empfindlichkeit: Anteil der Patienten, bei denen das Vorliegen einer Erkrankung (z.B. einer inneren Entzündung) durch den Test richtig angezeigt wurde, bzw. Anteil der Tiere mit ungünstigem Krankheitsverlauf, bei denen der Test positiv reagierte.

- Diagnostische bzw. prognostische Spezifität: Anteil der negativ reagierenden Patienten am Krankengut, bei denen keine der in Frage kommenden Erkrankungen (innere Entzündungen) vorlag, bzw. Anteil derjenigen Patienten, die eine gute Prognose hatten und bei denen der Test negativ ausfiel.

- Diagnostische Effektivität: Anteil richtiger Entscheidungen (bzw. Aussagen) des Tests.

- Prädiktiver Wert des positiven Ergebnisses: Wahrscheinlichkeit, mit der bei einem positiven

\footnotetext{
${ }^{3}$ Biuret-Methode, Fa. Boehringer Mannheim.

+ Celluloseacetat-Elektrophorese, Fa. Boskamp.

; Multifibrinogen-Testbesteck, Behringwerke.
} 
Testergebnis eine bestimmte Krankheit (in diesem Falle eine innere Entzündung) vorliegt bzw. eine schlechte Prognose gegeben ist.

- Prädiktiver Wert des negativen Ergebnisses: Maß für die Wahrscheinlichkeit, mit der bei einem negativen Testergebnis eine Erkrankung (innere Entzündung) ausgeschlossen werden kann bzw. eine gute Prognose besteht.

\section{Ergebnisse}

\section{Beziebung zwischen Testergebnis und Proteingebalt}

Der Vergleich der Reaktionszeiten des Glutaraldehyd-Tests mit der Summe aus $\gamma$ Globulin- und Fibrinogengehalt ergab einen negativen Korrelationskoeffizienten von $r=-0,81(n=64)$. Dagegen war die Korrelation zwischen den Testergebnissen und dem Gesamteiweißgehalt des Serums allein mit $r=-0,46(n=394)$ deutlich geringer.

\section{Ausfall des Tests bei schwerwiegenden inneren Entzündungen}

Die schwerwiegenden entzündlichen inneren Erkrankungen Perikarditis $(n=7)$, Endokarditis $(n=16)$, Reticuloperitonitis traumatica $(n=57)$, Peritonitis $(n=45)$, Pyelonephritis und metastatisch-eitrige Nephritis $(n=11)$ sowie Hepatitis apostematosa $(n=4)$ wurden als eine Gruppe zusammengefaßt. In 74 Fällen $(72,5 \%)$ war es möglich, die klinischen Diagnosen Reticuloperitonitis traumatica und Peritonitis durch eine Laparotomie, durch die Erhebung des Schlachtbefundes oder durch die Sektion zu sichern. Bei den erwähnten entzündlichen Herz- und Herzbeutel-, Nieren- und Lebererkrankungen wurde zur Sicherung der Diagnose bei 16 Tieren (42,1\%) eine Sektion durchgeführt oder das betreffende Organ bei der Schlachtung untersucht.

Die Testzeiten der insgesamt 140 an einer dieser Krankheiten leidenden Patienten sind (ohne Berücksichtigung der Krankheitsdauer) in der folgenden Tabelle wiedergegeben:

\begin{tabular}{cccccc}
\hline $\begin{array}{c}\text { Testzeit } \\
\text { min }\end{array}$ & $\leq 1$ & $>1-\leq 3$ & $>3-\leq 6$ & $>6-\leq 15$ & $>15$ \\
\hline $\begin{array}{c}\text { Anzahl } \\
\mathrm{n}\end{array}$ & 19 & 69 & 21 & 15 & 16 \\
\hline
\end{tabular}

Bei der Auswertung dieser Tabelle ist zu berücksichtigen, daß im Verlauf einer Entzündung die für ein positives Testergebnis erforderlichen hohen Fibrinogen- und $\gamma$ Globulingehalte in der Regel erst nach einigen Tagen erreicht werden (13). Insofern ist es von Interesse, daß eine signifikante Beziehung zwischen der im Vorbericht dieser Tiere angegebenen Erkrankungsdauer und dem Ausfall des Tests nicht zu erkennen war. Das zeigt einmal mehr, daß den vorberichtlichen Angaben zur Erkrankungsdauer oft nur beschränkter Wert beigemessen werden kann. Allerdings wurde für 8 von 16 Patienten mit Reaktionszeiten über 15 Minuten angegeben, daß sie nicht länger als 3 Tage erkrankt waren.

Einflu $\beta$ des Alters auf die Testergebnisse: In der nachfolgenden Tabelle ist, nach Altersklassen getrennt, der absolute und prozentuale Anteil der Patienten mit inneren Entzündungen an den jeweiligen Reaktionszeiten angegeben:

\begin{tabular}{lcccrrr}
\hline $\begin{array}{l}\text { Alter } \\
\text { (Jahre) }\end{array}$ & $\mathrm{n} \%$ & \multicolumn{5}{c}{ Reaktionszeit (min) } \\
\hline $1-\leq 3$ & $43(100)$ & $4(9,3)$ & $20(46,5)$ & $9(20,9)$ & $10(23,3)$ \\
$>3-\leq 6$ & $62(100)$ & $8(12,9)$ & $29(46,8)$ & $20(32,3)$ & $5(8,0)$ \\
$>6$ & $35(100)$ & $7(20,0)$ & $20(57,2)$ & $7(19,9)$ & $1(2,9)$ \\
\hline
\end{tabular}


Wie aus dieser Tabelle hervorgeht, lag der Anteil stark positiver Testreaktionen bei den über 6 Jahre alten Rindern deutlich höher als bei den bis zu 3 Jahre alten Tieren. Dagegen fand sich bei letzteren ein wesentlich höherer Prozentsatz falsch negativer Testergebnisse. Die Gruppe der 3-6 Jahre alten Rinder nahm diesbezüglich eine Mittelstellung ein.

Ergebnisse bei Testwiederbolung: Die Zeiten zwischen dem bei inneren Entzündungen erstmals durchgeführten Glutaraldehyd-Test und dem ersten Wiederholungstest betrugen durchschnittlich 2,6 Tage; zwischen dem ersten und dritten Test lagen im Mittel 5,1 Tage. Ein signifikanter Unterschied zwischen dem in der Regel bei der Einlieferung durchgeführten Test und den nachfolgenden Tests in Abhängigkeit vom Krankheitsverlauf — geheilt oder nicht geheilt — war nicht zu erkennen.

\section{Testergebnisse bei nichtentzündlichen Erkrankungen}

Bei 71 zum Vergleich untersuchten Patienten mit einem nichtentzündlichen Primärleiden ergab die klinische Untersuchung auch keinen Hinweis auf einen entzündlichen Nebenbefund (was jedoch das Vorliegen eines verborgenen Entzündungsprozesses nicht mit Sicherheit ausschließt). Die Reaktionszeiten dieser Gruppe sowie diejenigen der 3 Rinder mit ungestörtem Allgemeinbefinden finden sich in der folgenden Tabelle:

\begin{tabular}{cccccc}
\hline $\begin{array}{c}\text { Testzeit } \\
\text { min }\end{array}$ & $\leq 1$ & $>1-\leq 3$ & $>3-\leq 6$ & $>6-\leq 15$ & $>15$ \\
\hline $\begin{array}{c}\text { Anzahl } \\
\mathrm{n}\end{array}$ & 0 & 2 & 13 & 21 & 38 \\
\hline
\end{tabular}

\section{Diagnostischer Aussagewert der Testergebnisse}

Zur Beurteilung der Frage, ob sich der Glutaraldehyd-Test als Screening-Verfahren verwenden läßt, um generell Patienten mit entzündlichen Veränderungen von nicht entzündlich erkrankten Tieren zu unterscheiden, wurden diese beiden Gruppen miteinander verglichen. Die hierbei berechneten Maßzahlen zur Beschreibung des Aussagewertes der Testergebnisse sind in Tabelle 2 wiedergegeben. Bei insgesamt 359 Rindern waren entzündliche Veränderungen festzustellen; die Prävalenz, d. h. die Vorkommenshäufigkeit entzündlicher Befundc, liegt im erfaßten Krankengut mit 82,9\% außerordentlich hoch.

Die entsprechenden Maßzahlen für die „diagnostische Treffsicherheit“ des Glutaraldehyd-Tests bei der Erkennung schwerwiegender innerer Entzündungen im unselektierten Krankengut sind in Tabelle 3 aufgeführt.

Tabelle 4 zeigt die Werte, die man erhält, wenn man die Testergebnisse der Patienten mit schwerwiegenden inneren Entzündungen mit den bei jenen Tieren gefundenen Reaktionszeiten vergleicht, bei denen weder eine dieser Krankheiten noch Entzündungserscheinungen an anderen, der Untersuchung zugänglichen Organen - einschließlich der Lunge und Gebärmutter - festgestellt werden konnten. Diese Vergleichsgruppe setzt sich somit zusammen aus den nicht entzündlich erkrankten Patienten $(n=71)$ sowie jenen 3 Tieren, bei denen sich das Allgemeinbefinden als ungestört erwies.

\section{Prognostische Bedeutung der Testergebnisse}

In die Berechnung der Maßzahlen zur Charakterisierung der prognostischen Aussagekraft des Glutaraldehyd-Tests gingen nur die Daten derjenigen Patienten ein, deren weiteres Schicksal über den Zeitraum von 2 Monaten nach der Entlassung aus der Klinik in Erfahrung gebracht werden konnte.

Von 271 Rindern, bei denen ein entzündlicher Prozeß für den Krankheitsverlauf bestimmend war, wurden 84 geheilt und 187 Tiere nicht geheilt. Die Prävalenz einer 


\section{Tabelle 2}

Der Glutaraldehyd-Test in der Diagnostik entzündlicher Erkrankungen: Vergleich der Reaktionszeiten bei Rindern, bei denen entzündliche Krankheitsprozesse vorlagen, mit den Testzeiten der

Patienten, bei denen keine entzündlichen Veränderungen festgestellt werden konnten

\begin{tabular}{llllll}
\hline $\begin{array}{l}\text { Reaktionszeit } \\
\text { - Grenzwert }- \\
(\mathrm{min})\end{array}$ & $\begin{array}{l}\text { Diagnostische } \\
\text { Empfindlichkeit } \\
(\%)\end{array}$ & $\begin{array}{l}\text { Diagnostische } \\
(\%)\end{array}$ & $\begin{array}{l}\text { Diagnostische } \\
\text { Effektivität } \\
(\%)\end{array}$ & $\begin{array}{l}\text { Prädikt. Wert } \\
\text { des pos. Tests } \\
(\%)\end{array}$ & $\begin{array}{l}\text { Prädikt. Wert } \\
\text { des neg. Tests } \\
(\%)\end{array}$ \\
\hline $1(25)$ & 7,0 & 100,0 & 23,0 & 100,0 & 18,1 \\
$3(149)$ & 40,9 & 97,3 & 50,6 & 98,7 & 25,4 \\
$6(252)$ & 66,0 & 79,7 & 68,4 & 94,0 & 32,6 \\
$15(342)$ & 85,2 & 51,4 & 79,4 & 89,5 & 41,8 \\
\hline
\end{tabular}

Prävalenz der entzündlichen Veränderungen $=82,9 \%$

In Klammer: Anzahl der Tiere mit Reaktionszeiten $\leq$ Grenzwert;

bei 91 Rindern Reaktionszeit > 15 Minuten

\section{Tabelle 3}

Der Glutaraldehyd-Test in der Diagnostik schwerwiegender entzündlicher innerer Erkrankungen: Die Reaktionszeiten bei Tieren mit inneren Entzündungen verglichen mit den Testergebnissen bei den übrigen Patienten

\begin{tabular}{llllll}
\hline $\begin{array}{l}\text { Reaktionszeit } \\
- \text { Grenzwert } \\
(\mathrm{min})\end{array}$ & $\begin{array}{l}\text { Diagnostische } \\
\text { Empfindlichkeit Spezifität } \\
(\%)\end{array}$ & $\begin{array}{l}\text { Diagnostische } \\
(\%)\end{array}$ & $\begin{array}{l}\text { Diagnostische } \\
\text { Effektivität } \\
(\%)\end{array}$ & $\begin{array}{l}\text { Prädikt. Wert } \\
\text { des pos. Tests } \\
(\%)\end{array}$ & $\begin{array}{l}\text { Prädikt. Wert } \\
\text { des neg. Tests } \\
(\%)\end{array}$ \\
\hline $1(25)$ & 13,6 & 98,0 & 70,7 & 76,0 & 70,3 \\
$3(149)$ & 62,9 & 79,2 & 73,9 & 59,1 & 81,7 \\
$6(252)$ & 77,9 & 51,2 & 59,8 & 43,3 & 82,9 \\
$15(342)$ & 88,6 & 25,6 & 45,6 & 36,3 & 82,4 \\
\hline
\end{tabular}

Prävalenz der schwerwiegenden inneren Entzündungen $=32,3 \%$

In Klammer: Anzahl der Tiere mit Reaktionszeiten $\leq$ Grenzwert;

bei 91 Rindern Reaktionszeit > 15 Minuten

\section{Tabelle 4}

Der Glutaraldehyd-Test in der Diagnostik schwerwiegender entzündlicher innerer Erkrankungen: Vergleich der bei Patienten mit inneren Entzündungen gefundenen Reaktionszeiten mit den Testergebnissen der Rinder, bei denen ein nichtentzündlicher Krankheitsprozeß vorlag und bei denen darüber hinaus keine entzündlichen Nebenbefunde erhoben werden konnten, sowie mit denen der Tiere, bei denen das Allgemeinbefinden ungestört war

\begin{tabular}{llllll}
\hline $\begin{array}{l}\text { Reaktionszeit } \\
- \text { Grenzwert }- \\
(\mathrm{min})\end{array}$ & $\begin{array}{l}\text { Diagnostische } \\
\text { Empfindlichkeit Spezifität } \\
(\%)\end{array}$ & $\begin{array}{l}\text { Diagnos } \\
(\%)\end{array}$ & $\begin{array}{l}\text { Diagnostische } \\
\text { Effektivität } \\
(\%)\end{array}$ & $\begin{array}{l}\text { Prädikt. Wert } \\
\text { des pos. Tests } \\
(\%)\end{array}$ & $\begin{array}{l}\text { Prädikt. Wert } \\
\text { des neg. Tests } \\
(\%)\end{array}$ \\
\hline $1(19)$ & 13,6 & 100,0 & 43,5 & 100,0 & 37,9 \\
$3(90)$ & 62,9 & 97,3 & 74,8 & 97,8 & 58,1 \\
$6(124)$ & 77,9 & 79,7 & 78,5 & 87,9 & 65,6 \\
$15(160)$ & 88,6 & 51,4 & 75,7 & 77,5 & 70,4 \\
\hline
\end{tabular}

Prävalenz der schwerwiegenden inneren Entzündungen $=65,4 \%$ In Klammer: Anzahl der Tiere mit Reaktionszeiten $\leq$ Grenzwert; bei 54 Patienten Reaktionszeit $>15$ Minuten 
schlechten Prognose betrug somit $69 \%$. Dabei muß jedoch berücksichtigt werden, daß ein hoher Prozentsatz der hier als "nicht geheilt" aufgeführten Rinder aufgrund der Art der Erkrankung und unter Berücksichtigung der Wirtschaftlichkeit einer Therapie sogleich geschlachtet wurde. In Tabelle 5 sind die Werte für die prognostische Aussagekraft der Testergebnisse wiedergegeben. Die prognostische Empfindlichkeit repräsentiert den Anteil der nicht geheilten Tiere mit einer Reaktionszeit kleiner oder gleich dem Grenzwert; die prognostische Spezifität kennzeichnet den Anteil der Patienten mit einer über dem Grenzwert liegenden Reaktionszeit. Die Resultate werden im Rahmen der Diskussion interpretiert.

Tabelles

Prognostischer Aussagewert des Glutaraldehyd-Tests bei entzündlichen Erkrankungen des Rindes

\begin{tabular}{llllll}
\hline $\begin{array}{l}\text { Reaktionszeit } \\
\text { - Grenzwert }- \\
\text { (min) }\end{array}$ & $\begin{array}{l}\text { Prognostische } \\
\text { Empfindlichkeit Spezifität } \\
(\%)\end{array}$ & $\begin{array}{l}\text { Prognostische } \\
(\%)\end{array}$ & $\begin{array}{l}\text { Prognostische } \\
\text { Effektivität } \\
(\%)\end{array}$ & $\begin{array}{l}\text { Prädikt. Wert } \\
\text { des pos. Tests } \\
(\%)\end{array}$ & $\begin{array}{l}\text { Prädikt. Wert } \\
\text { des neg. Tests } \\
(\%)\end{array}$ \\
\hline $1(22)$ & 9,6 & 95,2 & 36,1 & 81,8 & 32,1 \\
$3(122)$ & 47,6 & 60,2 & 51,7 & 73,0 & 34,2 \\
$6(182)$ & 70,6 & 40,5 & 61,3 & 72,5 & 38,2 \\
$15(230)$ & 85,0 & 15,5 & 63,5 & 69,1 & 31,7 \\
\hline
\end{tabular}

Prävalenz einer ungünstigen Prognose $=69,0 \%$ (Anteil der nicht geheilten Patienten)

In Klammer: Anzahl der Tiere mit Reaktionszeiten $\leq$ Grenzwert;

41 Rinder hatten Reaktionszeiten $>15$ Minuten

Auf die Gruppe der „schwerwiegenden inneren entzündlichen Erkrankungen“ entfielen 135 Tiere, davon wurden 107 nicht geheilt; die Prävalenz einer schlechten Prognose lag somit bei 79,5\%. Dieser ungünstige Wert kam deshalb zustande, weil alle an Perikarditis, Endokarditis oder Hepatitis apostematosa erkrankten Rinder geschlachtet bzw. getötet wurden, sofern sie nicht verendet sind. Von den 11 Tieren mit entzündlichen Nierenerkrankungen war in einem Falle eine erfolgreiche Therapie möglich. Dagegen konnten immerhin 25 von 52 der an einem Fremdkörper erkrankten Rinder - zumeist handelte es sich um Tiere, die nach erfolgloser konservativer Therapie an die Klinik überwiesen worden waren - geheilt werden.

Aus dieser Aufstellung geht bereits hervor, daß hier zwischen unheilbaren und heilbaren Leiden differenziert werden muß. Beim gegenwärtigen Stand der wirtschaftlich vertretbaren therapeutischen Möglichkeiten ist das Vorliegen einer der oben genannten inneren Entzündungen, ausgenommen der Reticuloperitonitis traumatica, in der Regel gleichbedeutend mit einer schlechten Prognose, und das unabhängig von den jeweiligen Glutaraldehyd-Testergebnissen, die im eigenen Krankengut im Bereich von unter einer Minute bis über 15 Minuten lagen.

Bezogen auf das eigene Krankengut erscheint es nur bei der Reticuloperitonitis traumatica, bei der eine Heilungsmöglichkeit durchaus gegeben ist, überhaupt sinnvoll zu untersuchen, ob eine Beziehung zwischen Reaktionszeit und Krankheitsverlauf besteht (Tab.6). Unter Berücksichtigung der Prävalenz einer schlechten Prognose, die bei dieser Krankheit $51,9 \%$ betrug, errechnet sich der prädiktive Wert eines ungünstigen Krankheitsverlaufs für die Reaktionszeit bis zu einer Minute mit 66,7\%. Bei längeren Testzeiten unterscheidet er sich nicht deutlich von der Prävalenz. Umgekehrt beträgt der prädiktive Wert für eine günstige Prognose erst dann 66,6 \%, wenn die Reaktionszeit des Tests über 15 Minuten liegt. 
Tabelle 6

Prognostischer Aussagewert des Glutaraldehyd-Tests bei Reticuloperitonitis traumatica

\begin{tabular}{llllll}
\hline $\begin{array}{l}\text { Reaktionszeit } \\
\text { - Grenzwert }-\begin{array}{l}\text { Prognostische } \\
\text { (min) }\end{array}\end{array}$ & $\begin{array}{l}\text { Prognostische } \\
(\%)\end{array}$ & $\begin{array}{l}\text { Prognostische } \\
\text { Effektivität } \\
(\%)\end{array}$ & $\begin{array}{l}\text { Prädikt. Wert } \\
\text { des pos. Tests } \\
(\%)\end{array}$ & $\begin{array}{l}\text { Prädikt. Wert } \\
\text { des neg. Tests } \\
(\%)\end{array}$ \\
\hline $1(6)$ & 14,8 & 92,0 & 51,9 & 66,7 & 50,0 \\
$3(36)$ & 63,0 & 24,0 & 44,2 & 47,2 & 37,5 \\
$6(44)$ & 88,0 & 20,0 & 55,8 & 54,2 & 62,5 \\
$15(49)$ & 96,2 & 8,0 & 53,8 & 53,1 & 66,6 \\
\hline
\end{tabular}

Prävalenz einer ungünstigen Prognose $=51,9 \%$

In Klammer: Anzahl der Tiere mit Reaktionszeiten $\leq$ Grenzwert;

3 Patienten hatten Reaktionszeiten $>15$ Minuten, davon 2 Tiere geheilt,

1 Tier nicht geheilt

\section{Diskussion}

\section{Übereinstimmung zwischen Testergebnis und Proteingehalt}

Wie aus der Untersuchung hervorgeht, besteht eine gute, umgekehrt proportionale Korrelation $(\mathrm{r}=-0,81)$ zwischen den Reaktionszeiten des Glutaraldehyd-Tests und der Höhe der Fibrinogen- und $\gamma$-Globulingehalte im Blut. Erwartungsgemäß wesentlich weniger deutlich ist dagegen die Beziehung zwischen der Höhe des Serum-Gesamteiweißgehalts und den Testergebnissen $(r=-0,46)$, eine Bestätigung der schon von anderen Untersuchern $(14,16,23,24)$ gemachten Beobachtung, wonach in erster Linie die $\gamma$ Globuline und das Fibrinogen für die Reaktion verantwortlich sind.

Damit handelt es sich bei dem Glutaraldehyd-Test um eine ausgezeichnete Schnellmethode zum Nachweis dieser beiden Eiweißkörper im Vollblut. Wie bei anderen klinischchemischen Befunden ist jedoch auch hier eine begriffliche Trennung erforderlich $z$ wischen der Zuverlässigkeit des Analysenresultats und der Zuverlässigkeit, mit der eine diagnostische oder prognostische Fragestellung beantwortet wird. Ob dieser Test für die praktische klinische Anwendung beim Rind in Frage kommt, hängt deshalb allein davon ab, inwieweit den mit dem Test erfaßten Eiweißfraktionen bei bestimmten Erkrankungen diagnostische und prognostische Bedeutung zukommt und welche Faktoren die Aussagekraft einschränken können.

\section{Diagnostische Bedeutung des Glutaraldehyd-Tests}

Beim Einsatz als Suchtest zur Erkennung entzündlicher Erkrankungen wurde als Entscheidungskriterium die Reaktionszeit von 15 Minuten vorgeschlagen (16). Legt man diesen Grenzwert zugrunde, beträgt nach unserer Kasuistik die Wahrscheinlichkeit (prädiktiver Wert) $89,5 \%$, daß bei einem innerhalb von 15 Minuten positiv reagierenden Glutaraldehyd-Test eine entzündliche Veränderung vorliegt. Bei der Beurteilung dieses Ergebnisses ist jedoch zu berücksichtigen, daß die Prävalenz der entzündlichen Erkrankungen im ausgewerteten Krankengut mit 85,9\% außerordentlich hoch lag. Errechnet man den prädiktiven Wert unter Zugrundelegung einer geringeren Entzündungshäufigkeit, so liegt dieser wesentlich niedriger. Die diagnostische Aussagekraft des GlutaraldehydTests in dieser Indikation ist demnach als recht gering einzuschätzen. Mit kürzeren Reaktionszeiten erhöht sich zwar die Wahrscheinlichkeit, daß einem positiven Testergebnis eine klinisch-manifeste Entzündung zugrunde liegt - sie beträgt bei 6 Minuten bereits $94 \%$ - doch werden dabei nur $66 \%$ der entzündlich erkrankten Patienten erfaßt. Umgekehrt war nur bei etwa der Hälfte der Tiere, die bei der klinischen Untersuchung frei von erkennbaren entzündlichen Veränderungen waren, der Test nach 15 Minuten noch negativ. 
Die Schwierigkeit einer richtigen Klassifizierung der Patienten anhand der Ergebnisse des Glutaraldehyd-Tests, von der bereits MARTENs (18) berichtet hat, resultiert vermutlich daraus, daß sich die Häufigkeitsverteilungen der Fibrinogen- und $\gamma$-Globulingehalte gesunder, nichtentzündlich und entzündlich erkrankter Rinder teilweise überlappen. Die individuelle und altersabhängige Variation der Plasmaproteine spielt dabei ebenso eine Rolle wie Einflüsse einer Hämokonzentration oder das häufige Vorkommen subklinischer entzündlicher Krankheitsprozesse. Selbst Schutzimpfungen gegen die Maul- und Klauenseuche können den Serum-Globulingehalt derart erhöhen, daß sich der Anstieg mit der Formolgel-Probe nachweisen läßt (29). Möglicherweise kann auch bei einzelnen Tieren eine angeborene Dysgammaglobulinämie vorliegen (3). Kompliziert wird die klinische Beurteilung zum zweiten dadurch, daß oft neben einem im Vordergrund stehenden nichtentzündlichen Prozeß entzündliche Veränderungen bestehen. Auffallend häufig fanden sich zum Beispiel bei Patienten mit Labmagenverlagerungen Endometritiden; daneben bestanden entzündliche Erkrankungen des Euters, der Harnorgane, des Bewegungsapparats sowie Leberegelbefall. Die Reaktionszeiten des Glutaraldehyd-Tests bewegten sich in diesen Fällen zwischen 3 und 15 Minuten.

Schwerwiegende innere Erkrankungen sind beim Rind aufgrund ihrer teilweise recht unspezifischen Symptomatik oft schwierig zu diagnostizieren. Gerade bei dieser Krankheitsgruppe sollte jedoch wegen der Intensität und dem Umfang der Entzündungsprozesse mit starken Auswirkungen auf die Plasmaproteinzusammensetzung zu rechnen sein. Nach unseren Ergebnissen (Tab. 3) ist es jedoch nicht möglich, aus einem unselektierten Patientengut allein anhand des Ausfalls des Glutaraldehyd-Tests Tiere mit schwerwiegenden inneren Entzündungen herauszufinden. Allenfalls eine Reaktionszeit bis zu einer Minute legt den Verdacht auf eine solche Erkrankung nahe. Im ausgewerteten eigenen Krankengut zeigten aber nur 13,6\% der an einer schwerwiegenden inneren Entzündung leidenden Patienten ein derartiges Testergebnis. Wie schon vorne dargelegt wurde, bestimmen die Intensität und Chronizität eines entzündlichen Krankheitsprozesses, unabhängig von dessen Lokalisation, das Ausmaß des Fibrinogen- und $\gamma$-Globulinanstiegs.

Der Glutaraldehyd-Test kann somit eine gründliche klinische Untersuchung nicht ersetzen; sie ist geradezu Vorbedingung für seine sinnvolle Anwendung. Erst wenn Entzündungsprozesse an äußerlich zugänglichen Organen ausgeschlossen worden sind, kann mit hinreichender Sicherheit aus einem positiven Testergebnis gefolgert werden, daß eine innere Entzündung vorliegen muß (Tab.4). Die Ausgangslage hat sich hier insofern geändert, als der Test nicht mehr als Suchtest, sondern zur Stützung einer Verdachtsdiagnose eingesetzt wird. Bei dieser Vorgehensweise erhöht sich die diagnostische Treffsicherheit beträchtlich; der prädiktive Wert liegt für die Testzeit von 3 Minuten bei $97,8 \%$, für 6 Minuten beträgt der $87,9 \%$. Es bleibt aber die unbefriedigende Tatsache, daß selbst bei einem Testwert von 6 Minuten schon mit 12,1\% falsch positiven Ergebnissen gerechnet werden muß.

Umgekehrt betrug bei 16 Tieren $(11,4 \%)$ mit einer schwerwiegenden inneren Entzündung die Reaktionszeit über 15 Minuten; die Proteinfraktionen lagen dabei im Normalbereich. Bei der Interpretation dieser falsch negativen Ergebnisse könnte bei 8 Tieren der Zeitfaktor eine Rolle gespielt haben. Diese Patienten waren seit höchstens drei Tagen erkrankt; offenbar hat diese Erkrankungsdauer nicht ausgereicht, um deutlich erhöhte Fibrinogen- und $\gamma$-Globulinspiegel zu bewirken. Unterstützt wird diese Vermutung durch die Beobachtung, daß in drei Fällen der Test zwei Tage später deutlich positiv reagierte. Im Einzelfall mögen auch immunsuppressive Einflüsse vorhanden gewesen sein. Diskutiert wird in diesem Zusammenhang die Anwendung von Glukokortikoiden (5). Zumindest bei drei Tieren steht fest, daß sie mit Kortikosteroiden vorbehandelt worden waren. Von einem terminalen Stadium, in dem die Fibrinogenspiegel bei schweren Entzündungen ebenfalls erniedrigt sein sollen (19), kann in drei Fällen gesprochen werden.

Offenbar besteht ein deutlicher Zusammenhang zwischen dem Alter der Rinder und der Ausbildung stark positiver bzw. negativer Testreaktionen. Es fällt auf, daß 10 der 16 Patienten mit falsch negativem Test erst zwischen einem und drei Jahren alt waren; das 
entspricht einem Anteil von 23,25\% falsch negativer Ergebnisse bei schwerwiegenden inneren Entzündungen in dieser Altersklasse. Umgekehrt betrug der Anteil der falsch negativen Resultate in der Altersklasse über 6 Jahre nur 2,85\%. Dagegen ergab sich bei den stark positiven Testergebnissen ein genau gegensätzliches Bild. Diese Ergebnisse werden durch die Angaben anderer Autoren $(10,15,17)$ bestätigt, wonach der $\gamma$-Globulinspiegel mit zunehmendem Alter signifikant ansteigt. Man kann vermuten, daß im Verlauf einer entzündlichen Erkrankung bei alten Tieren - ausgehend von einem bereits relativ hohen Basiswert - schneller der Bereich erreicht wird, in dem der Test positiv reagiert. Bei gleichem Krankheitsprozeß ist daher bei einem alten Rind eher ein stark positives Glutaraldehyd-Testergebnis zu erwarten, wohingegen bei einem ein bis drei Jahre alten Tier der Test auch negativ sein kann.

Der Verlauf einer Entzündung soll sich anhand wiederholter Fibrinogen- und $\gamma$ Globulinbestimmungen verfolgen lassen $(3,10,15,19)$. Dabei muß man sich aber vergegenwärtigen, daß sich wesentliche Änderungen einmal erhöhter Fibrinogen- und $\gamma$ Globulinspiegel in Zeiträumen von mehreren Tagen bis Wochen vollziehen. Bei den Klinikpatienten haben offenbar die zwischen den einzelnen Tests liegenden Intervalle durchschnittlich 2,6 Tage zwischen 1. und 2. Test und 5,1 Tage zwischen 1. und 3. Test nicht ausgereicht, um signifikante Unterschiede der Testreaktionen zu bewirken. Allenfalls zu Beginn einer entzündlichen Erkrankung deutet eine bei einer Testwiederholung kürzere Reaktionszeit darauf hin, daß es sich um das Initialstadium einer Entzündung handeln muß.

\section{Prognostische Bedeutung des Glutaraldehyd-Tests}

Verschiedentlich wurde auf die prognostische Bedeutung erhöhter Fibrinogenwerte $(3,5,19)$ und $\gamma$-Globulinspiegel $(6,23,24)$ hingewiesen. Im Vergleich der Ergebnisse des Glutaraldehyd-Tests mit dem Verlauf der Krankheit bei all den Patienten, bei denen ein entzündlicher Prozeß im Vordergrund stand, ergab sich nur für die sehr kurze Reaktionszeit von bis zu einer Minute eine prognostisch relevante Aussagekraft (Tab.5). Die Wahrscheinlichkeit einer ungünstigen Prognose beträgt hier $81,8 \%$, jedoch hatten nur 9,6\% der entzündlich erkrankten Tiere mit einem ungünstigen Krankheitsverlauf eine Testzeit von bis zu einer Minute.

Bei inneren Entzündungen hängt die Prognosestellung nicht allein von dem Umfang des Krankheitsprozesses ab, sondern in entscheidendem Maße von dessen Ursache bzw. Art und seiner Lokalisation und damit von den therapeutischen Möglichkeiten und der Wirtschaftlichkeit einer Behandlung. Bei der Fremdkörpererkrankung sollen sich prognostisch günstige Fälle von ungünstigen mit Hilfe des Glutaraldehyd-Tests unterscheiden lassen $(6,23,24)$. Nach den vorliegenden Untersuchungen (Tab.6) liegt bei der Reticuloperitonitis traumatica die Wahrscheinlichkeit eines ungünstigen Verlaufs bei den Patienten mit Reaktionszeiten bis zu einer Minute (prädiktiver Wert 66,7\%) etwas über der Prävalenz der nichtgeheilten Tiere $(51,9 \%)$, und umgekehrt hat ein an einem Haubenfremdkörper erkranktes Rind mit einem Glutaraldehyd-Testwert von über 15 Minuten eine etwas größere Heilungschance $(66,6 \%)$. Diese Ergebnisse sind aber nur von begrenzter praktischer Bedeutung, da einerseits jeweils nur wenige Tiere $(14,8 \%$ bzw. 8,0\%) diese extremen Testzeiten aufwiesen, andererseits selbst von den 6 Patienten mit einer Reaktionszeit bis zu einer Minute 2 Tiere geheilt werden konnten. Selbst das Vorhandensein von Abszessen schließt eine Heilung nicht aus (1).

Bei der Interpretation der in dieser Untersuchung errechneten prädiktiven Werte muß berücksichtigt werden, daß die Prävalenz der entzündlichen Erkrankungen, und insbesondere die der schwerwiegenden inneren Entzündungen, bei den Klinikpatienten relativ hoch lag. Die Prävalenz der entzündlichen Erkrankungen in der Praxis läßt sich nur schwer abschätzen; es ist jedoch zu vermuten, daß sie eher niedriger anzusetzen ist. Da der prädiktive Wert eines Testergebnisses von der Prävalenz abhängt, hätte das zur Folge, daß hier die prädiktiven Werte der positiven Testergebnisse entsprechend niedriger lägen. 


\section{Zusammenfassung}

An 433 Rindern wurde die klinische Bedeutung des Glutaraldehyd-Tests, einer Eiweißlabilitätsprobe zur Fibrinogen- und $\gamma$-Globulinbestimmung im Vollblut, untersucht. Die Korrelation zwischen der Konzentration dieser Plasmaproteine und den Reaktionszeiten war umgekehrt proportional $(r=-0,81)$. Zur Beurteilung des Aussagewertes der Testergebnisse wurden die diagnostische und prognostische Empfindlichkeit, Spezifität, Effektivität sowie die prädiktiven Werte berechnet. Danach ist in gewissem Umfang eine Aussage darüber möglich, ob eine entzündliche Erkrankung vorliegt oder nicht. Wenn durch die klinische Untersuchung äußere Entzündungsprozesse ausgeschlossen werden können, beträgt der prädiktive Wert für das Vorliegen einer inneren Entzündung bei Ablesung des Tests nach 3 Minuten 97,8\%, nach 6 Minuten 87,9\%. Es muß allerdings bei dem Grenzwert von 6 Minuten schon mit 12,1\% falsch positiven Testergebnissen gerechnet werden. Eine Reaktionszeit über 15 Minuten hatten 11,4\% der Patienten mit schwerwiegenden inneren Entzündungen; die Hälfte davon war jedoch nicht länger als 3 Tage erkrankt. Eine prognostische Aussage allein aufgrund der Reaktionszeit ist nur bedingt möglich, da der Verlauf einer Entzündung nicht nur von deren Intensität und Umfang, sondern entscheidend von der Art und Lokalisation bestimmt wird.

\section{Danksagung}

Für die Unterstützung bei der statistischen Auswertung danken wir Herrn Prof. Dr. Dr. OsterkorN vom Institut für Tierzucht der Tierärztlichen Fakultät der Universität München.

\section{Summary}

\section{The glutaraldehyde test in cattle - its usefulness for diagnosis and prognosis of internal inflammatory conditions}

In 435 cattle the clinical significance of the glutaraldehyde test, a protein lability test for estimation of fibrinogen and $\gamma$-globulin in whole blood, was examined. The correlation between the concentration of these plasma proteins and the reaction time was inversely proportional $(\mathrm{r}=0.81)$. The significance of the test in respect of diagnostic and progrostic sensitivity, specificity and effectiveness, together with its predictive value, was assessed. To some degree the test results make it possible to determine whether an inflammatory process is present or not. When examination is able to exclude external inflammatory processes, the predictive value for the presence of an internal inflammatory process is obtainable after 3 minutes in $97.8 \%$ and after 6 minutes in $87.9 \%$. However, with a reading of 6 minutes one has to contend with $11.4 \%$ of false positive results. A reaction after 15 minutes was given by $11.4 \%$ of patients with severe internal inflammation but half of these patients had not been affected for more than 3 days. A prognostic evaluation based solely on the reaction time of the test is only possible conditionally, depending since the course of the inflammation depends not only on its internal intensity and extent but also on its nature and localization.

\section{Résumé}

Test au glutaraldéhyde chez le bovin - son emploi pour le diagnostic et le pronostic des inflammations internes

La signification clinique du test au glutaraldéhyde, une épreuve de labilité des protéines pour la détermination du fibrinogène et des $\gamma$-globulines dans le sang entier, a été examinée chez 433 bovins. La corrélation entre la concentration de ces protéines du plasma et des temps de réaction fut inversement proportionnelle $(\mathrm{r}=-0,81)$. On a calculé la sensibilité du diagnostic et du pronostic, la spécificité, l'efficacité et les valeurs de prédiction pour évaluer les données des résultats du test. Il fut possible dans un certain cadre d'envisager la présence ou l'absence d'une maladie inflammatoire. Si des processus inflammatoires externes peuvent être exclus par l'examen clinique, la valeur de prédiction sur la présence d'une inflammation interne à la lecture du test est de $97,8 \%$ après 3 minutes 
et de $87,9 \%$ après 6 minutes. Il faut toutefois compter avec un $12,1 \%$ des résultats faussement positifs du test avec la valeur limite de 6 minutes. 11,4\% des patients atteints de graves inflammations internes ont eu un temps de réaction dépassant 15 minutes; la moitié ne fut cependant malade plus de 3 jours. Une indication de pronostic est improbable sur la seule donnée du temps de réaction, car le déroulement d'une inflammation ne se détermine pas seulement sur son intensité et son étendue mais de façon plus déterminante sur la base de la nature et de sa localisation.

\section{Resumen \\ La prueba del glutaraldehido en los vacunos - su utilidad para el diagnóstico y pronóstico de las inflamaciones internas}

Se analizó en 433 vacunos la significación del test del glutaraldehido, una prueba de labilidad proteica en la valoración de fibrinógeno y globulinas $\gamma$ en sangre entera. La correlación entre la concentración de estas plasmaproteínas y los tiempos de reacción era inversamente proporcional $(r=-0,81)$. Para la estimación del valor testimonial de los resultados de la prueba, se calcularon la sensibilidad diagnóstica y pronóstica, la efectividad y los valores predictivos. Después resulta posible, en cierto grado, la deposición sobre si existe una enfermedad inflamatoria o no. Si se pueden excluir los procesos inflamatorios externos mediante la exploración clínica, importa el valor predictivo sobre la presencia de una inflamación interna al realizar la lectura de prueba a los 3 minutos el 97,8\%, mientras que tras 6 minutos el $87,9 \%$. Ciertamente que ya hay que contar con el valor límite de 6 minutos con un $12,1 \%$ de resultados de prueba falsamente positivos. Un tiempo de reacción superior a 15 minutos tenía el $11,4 \%$ de los pacientes con inflamaciones internas de gravedad; sin embargo, la mitad de ellos no estaba enfermo más de 3 días. Solo es posible, de forma condicionada, hacer una afirmación pronóstica en virtud del tiempo de reacción, puesto que el curso de una inflamación no se define solo por la intensidad y cuantía, sino decisivamente por la índole y su localización.

\section{Literaturverzeichnis}

1. Diernhofer, M., und G. Dirksen, 1962: Behandlung und Heilungsaussichten von Bauchhöhlenabszessen beim Rind. Dtsch. Tierärztl. Wschr. 69, 471-474.

2. Dubensky, R.A., and M.E. WhITE, 1983: The sensitivity, specificity and predictive value of total plasma protein in the diagnosis of traumatic reticuloperitonitis. Can. J. Comp. Med. 47, 241-244.

3. Ек, N., 1972: The quantitative determination of fibrinogen in normal bovine plasma and in cows with inflammatory conditions. Acta vet. scand. 13, 175-184.

4. Galen, R. S., und S. R. Gambino, 1979: Norm und Normabweichung klinischer Daten. Gustav Fischer Verlag, Stuttgart, New York.

5. Garry, F.B., 1984: Plasma fibrinogen measurement: Prognostic value in calf bronchopneumonia? Zbl. Vet. Med. A 31, 361-369.

6. Van den Hende, C., W. Oyaert, E. Muylle, and K. Vlaminck, 1980: Estimation of the glutaraldehyde coagulation test for field use in detection of hypo- and hypergammaglobulinaemia. Proceedings of the first meeting of the Academic Society for Large Animal Veterinary Medicine, Glasgow, September 8-9, 1980.

7. HopwOOD, D., 1969: A comparison of the crosslinking abilities of glutaraldehyde, formaldehyde and $\alpha$-hydroxyadipaldehyde with bovine serum albumin and casein. Histochemie 17, 151-161.

8. Hopwood, D., C. R. Allen, and M. MCCABE, 1970: The reactions between glutaraldehyde and various proteins. Histochem. J. 2, 137-150.

9. Lauerman, L. H., R. Ruppanner, B. B. Norman, C. J. Adams, and T. B. Farver, 1982: Metabolic and cellular profile testing in calves maintained under feedlot conditions: Protein fractions and lactate dehydrogenase isoenzymes - Changes over time. Am. J. Vet. Res. 43, $884-886$.

10. Liberg, P., 1973: The formol-gel reaction in cattle. Acta vet. scand. 14, 712-722. 
11. LiBerg, P., 1977 a: Agarose gel electrophoretic fractionation of serum proteins in adult cattle. I. A study of clinically healthy cows. Acta vet. scand. 18, 40-53.

12. Liberg, P., 1977 b: Agarose gel electrophoretic fractionation of serum proteins in adult cattle. II. A study of cows with different diseases. Acta vet. scand. 18, 335-338.

13. LIBERG, P., 1978: The fibrinogen concentration in blood of dairy cows and its influence on the glutaraldehyde and formol-gel test reactions. Acta vet. scand. 19, 413-421.

14. LiberG, P., 1981: Glutaraldehyde and formol-gel tests in bovine traumatic peritonitis. Acta vet. scand. 22, 78-84.

15. Liberg, P., 1982: Blood protein screening in healthy and diseased cattle. Agarose gel electrophoresis, the formol-gel and glutaraldehyde test. Thesis Skara.

16. Liberg, P., B. Pehrson, and M. Sandholm, 1975: The value of the glutaraldehyde and formaldehyde tests in evaluation of the globulin level in bovine blood. Acta vet. scand. 16, $236-243$.

17. Mallard, B. A., E. B. Burnside, J. H. Burton, and B. N. Wilkie, 1983: Variation in serum immunoglobulins in Canadian Holstein-Frisians. J. Dairy Sci. 66, 862-866.

18. Martens, H. H., 1977: Untersuchungen mit der Glutaraldehydprobe nach Sandholm im Vollblut gesunder und kranker Rinder. Vet. med. Diss. Hannover.

19. McSherry, B. J., F. D. Horney, and J. J. DE Groot, 1970: Plasma fibrinogen levels in normal and sick cows. Can. J. Comp. Med. 34, 191-197.

20. Miclaus, J., G. Espersen, and P. HJorth, 1973: Plasma protein composition in cattle affected with acute peritonitis. Nord. Vet.-Med. 25, 570-574.

21. NANSEN, P., 1972: Selective immunoglobulin deficiency in cattle and susceptibility to infection. Acta path. microbiol. scand. Section B 80, 49-54.

22. Sabattini, D. D., K. Bensch, and R. J. Barrnetr, 1963: Cytochemistry and electron microscopy. The prevention of cellular ultrastructure and enzymatic activity by aldehyde fixation. $J$. Cell Biol. 17, 19-58.

23. SAndholm, M., 1974 a: A preliminary report of a rapid method for the demonstration of abnormal gammaglobulin levels in bovine whole blood. Res. vet. Sci. 17, 32-35.

24. Sandholm, M., 1974 b: Die Feststellung der Hyper- $\gamma$-Globulinämie unter Praxisbedingungen. Tierärztl. Prax. 2, 237-240.

25. Sutron, R.H., and B. Hobman, 1975: The value of plasma fibrinogen estimations in cattle: A comparison with total leucocyte and neutrophil counts. New Zealand Vet. J. 23, No. 3, 21-27.

26. Sснаснт, P., 1962: Untersuchungen über den Fibrinogengehalt im Blut bei inneren Erkrankungen des Rindes. Vet. med. Diss. Hannover.

27. Tімм, D., 1969: Mikroelektrophoretische Serumeiweißuntersuchungen an Rindern mit entzündlich-infizierten Krankheitsprozessen. Vet. med. Diss. Hannover.

28. Vecchio, T.J., 1966: Predictive value of a single diagnostic test in unselected populations. New Engl. J. Med. 274, 1171-1173.

29. WEHMEYER, P., 1954: Variation in the composition of the blood in cows immunized against footand mouth-disease. Acta path. microbiol. scand. 34, 591-602. 